\title{
FY 06 Status of System Interface and Support Systems R \& D Areas
}

\author{
S.R. Sherman
}

September 2006

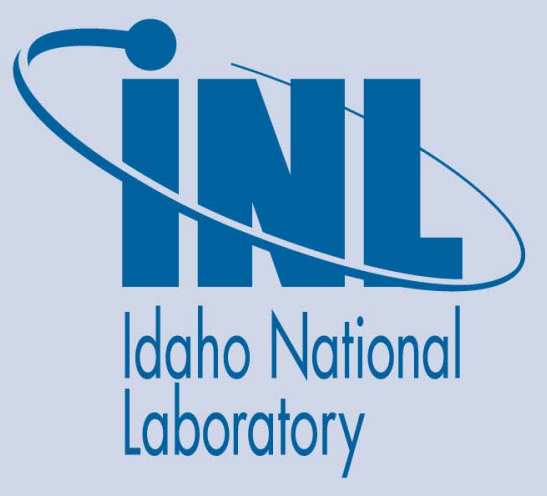

The INL is a U.S. Department of Energy National Laboratory operated by Battelle Energy Alliance 
INL/EXT-06-11728

\section{FY 06 Status of System Interface and Support Systems R \& D Areas}

S.R. Sherman

September 2006

\section{Idaho National Laboratory}

Idaho Falls, Idaho 83415

Prepared for the

U.S. Department of Energy

Office of Nuclear Energy

Under DOE Idaho Operations Office

Contract DE-AC07-05ID14517 


\section{ABSTRACT}

This document provides a summary of research and development activities performed in the Systems Interface and Support Systems area of the DOE Nuclear Hydrogen Initiative in FY 2006. Project cost and performance data obtained from the PICS system are presented and analyzed. Brief summaries of accomplishments and references are provided. A mapping of System Interface and Support Systems technical issues versus the work performed is updated and presented. Lastly, near-term research plans are given, and a description of the new UNLV high temperature heat exchanger program structure is provided. 


\section{CONTENTS}

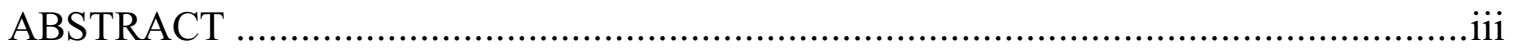

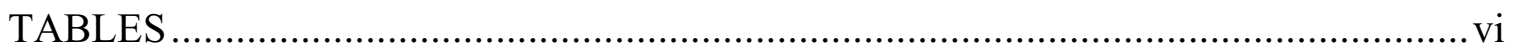

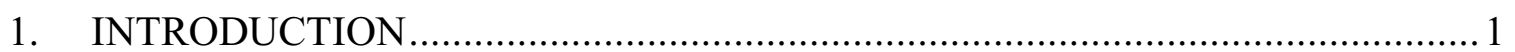

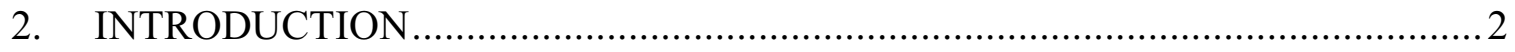

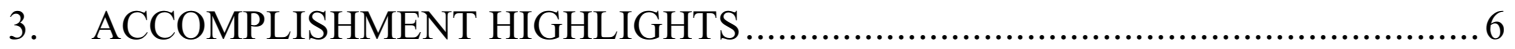

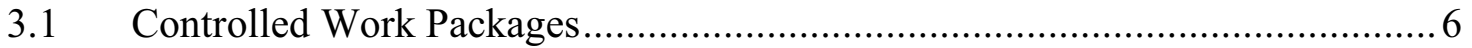

3.2 General Work Packages .......................................................................... 9

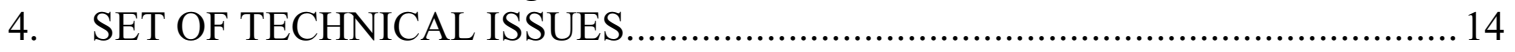

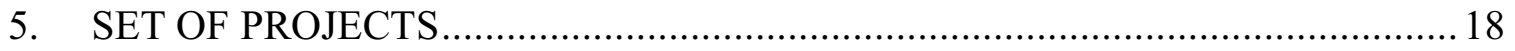

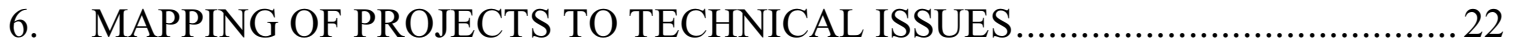

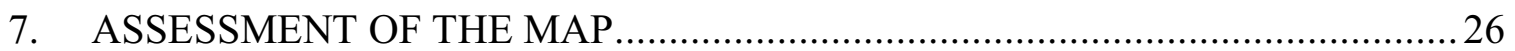

8. RESEARCH AND DEVELOPMENT DIRECTIONS FOR FY07 ........................ 28

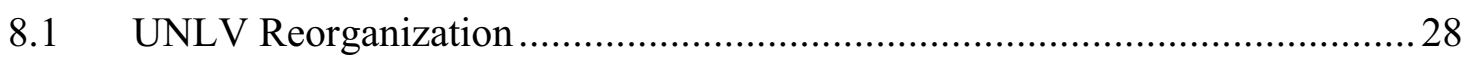

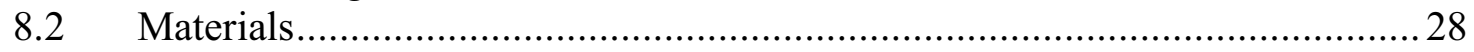

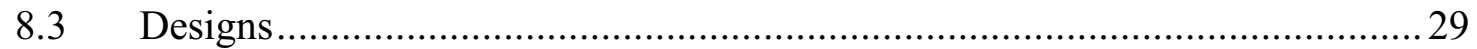

8.4 Balance of Plant and Infrastructure ........................................................ 30

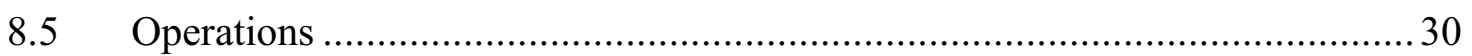

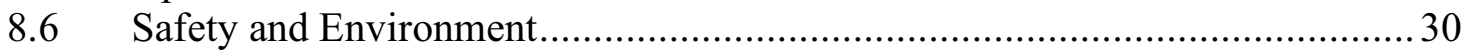

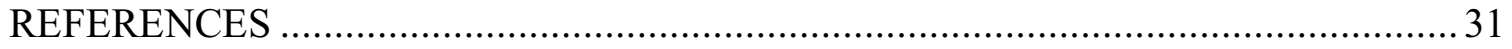

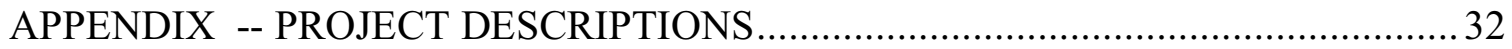

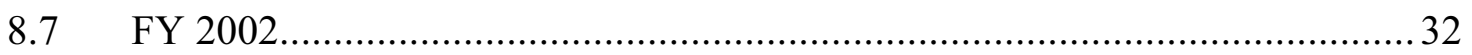

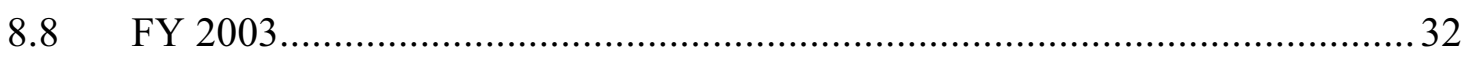

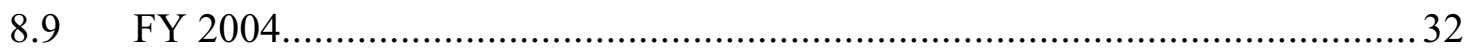

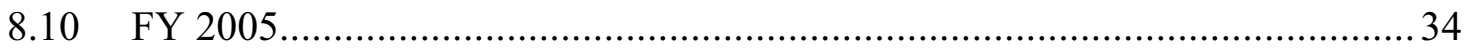

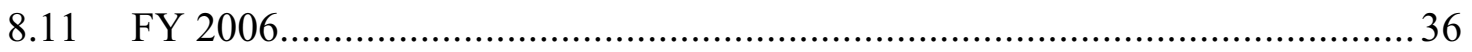




\section{TABLES}

Table 1. DOE NHI Yearly Funding ....................................................................... 1

Table 2. SI\&SS Controlled Work Packages for FY06 ........................................... 3

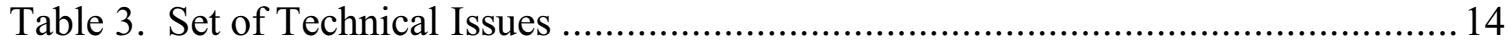

Table 4. Set of System Interface and Supporting Systems Projects ............................ 18

Table 5. Set of Relevant Thermochemical and HTE Projects .................................... 20

Table 6. Map of Projects and Issues........................................................................ 22 


\section{INTRODUCTION}

The System Interface and Support Systems area under the US Department of Energy (DOE) Nuclear Hydrogen Initiative (NHI) is responsible for developing the technologies needed to connect a high-temperature nuclear reactor to a nuclear hydrogen production plant. Also falling into this area are efforts to develop the balance-of-plant components of the nuclear hydrogen plants, and the identification of infrastructure needs for those plants. Overall system safety and environmental analyses are an important part of this technical area too. This technical area is one of three research areas of the DOE NHI. The other technical areas are the Thermochemical area and the High Temperature Electrolysis area.

The System Interface and Support Systems (SI\&SS) area has been an active area of research since 2004, as evidenced by the total funding summaries shown in Table 1.

Table 1. DOE NHI Yearly Funding

\begin{tabular}{|l|c|c|c|c|}
\cline { 2 - 5 } \multicolumn{1}{c|}{} & FY 2004 & FY 2005 & FY 2006 & $\begin{array}{c}\text { FY 2007 } \\
\text { (Projection) }\end{array}$ \\
\hline Funding $(\$ M)$ & 1.86 & 2.79 & 2.90 & 2.0 to 6.0 \\
\hline
\end{tabular}

Nearly all of the funding has been used to study fundamental or lower-level items related to design and construction of the connecting interface. These technical items include examination of candidate high-temperature materials, corrosion behaviors, basic compact heat exchanger designs, and related topics. Some work has been performed to understand the influence of connection length on the overall safety aspects of a combined nuclear plant/hydrogen plant facility, but most work has focused on feasibility issues at the component level.

In FY06, SI\&SS research was performed at a number of laboratories. Argonne National Laboratory, Idaho National Laboratory, and Oak Ridge National Laboratory perform were involved in technical management, system modeling, and system safety analysis activities. The University of Nevada Las Vegas and its sub-contractors (Ceramatec Inc., General Atomics, Massachusetts Institute of Technology, and the University of California - Berkeley) performed detailed experiments and modeling that is focused on high temperature heat exchanger development.

This document provides a summary of research and development activities performed in the Systems Interface and Support Systems area of the DOE Nuclear Hydrogen Initiative for the fiscal year 2006. This summary includes work performed at all of the locations involved. Project cost and performance data obtained from the Program Information Collection System (PICS) are presented and analyzed. Brief summaries of accomplishments and references are provided. A mapping of System Interface and Support Systems technical issues versus the work performed is updated and presented. Lastly, near-term research plans are given, and a description of the new UNLV high temperature heat exchanger program structure is provided. 


\section{INTRODUCTION}

Work in the DOE NHI is governed by work packages. Work packages are informal contracts between the US DOE and the laboratories or universities performing work that state the work scope, budget, milestones, deliverables, and timetables for individual work tasks. A work package is applicable to the current fiscal year, but may contain information about work to be performed in future consecutive fiscal years.

The DOE NHI distinguishes between controlled work packages and general work packages. Controlled work packages are used at the national laboratories and other organizations operated or sub-contracted by a contractor working for DOE. A general work package that is not a controlled work package is generally used for organizations, such as the University of Nevada Las Vegas (UNLV), that is not directly working for DOE.

In FY06, work was performed at three national laboratories using controlled work packages: Argonne National Laboratory (ANL), Idaho National Laboratory (INL), and Oak Ridge National Laboratory (ORNL). In broad terms, ANL was tasked with assisting INL in the development of steady-state system models for the combined nuclear plant/hydrogen plant facility and in the performance of an I-NERI project with the Korea Atomic Energy Research Institute (KAERI). The INL was assigned a leadership role in the NHI program to serve as technical director of SI\&SS research and also performed system modeling work with ANL as part of the I-NERI agreement with KAERI, coordinated exchanges of system interface information with the Commisariat à l'Energie Atomique (CEA) under an existing I-NERI agreement, revised balance-of-plant and plant spacing reports from FY05, and began work with ORNL to develop a new NHI Materials and Components Test Plan. ORNL served as lead editor for the development of a new NHI Materials and Components Test Plan and worked with the INL to achieve this goal.

PICS was used to track program performance for the controlled work packages. In PICS, a baseline schedule (Base Cost Work Scheduled or BCWS) was established at the start of the work packages, and the Base Cost Work Performed (BCWP), and Actual Cost Work Performed (ACWP) were recorded monthly. Cost and schedule variances were calculated based on these numbers and were tracked over the work packages' periods of performance. Although it is said that one cannot plan for a breakthrough in scientific research, using these performance metrics allows program managers to monitor the progress of the work and to take corrective actions in terms of schedule, budget, and work scope when trends indicate significant deviations from the BCWP.

Table 1 shows the PICS numbers for the controlled work packages. Actual numbers are provided for the first three quarters, and projected numbers are provided for the $4^{\text {th }}$ quarter since PICS information for September will not be available until October 2006. Projections can be made based on available trends for the $4^{\text {th }}$ quarter and the projected results calculated. Overall, $\$ 1,144,085$ was provided to the participating national laboratories for work, and $\$ 1,101,906$ in expenses were baselined for work to be performed in FY06. Since all work tasks in the work packages will be completed, the schedule variance (SV\%) will be zero at the end of the fiscal year. Because the actual cost of performing the work was below the predicted cost, the cost variance $(\mathrm{CV} \%)$ is predicted to be about $+9 \%$ at the end of the year. The major contributor to the cost variance was the INL in the $3^{\text {rd }}$ quarter. $A+27 \%$ cost variance occurred at the INL at that time due to the completion of two work activities (i.e., Balance-of-Plant report revision, 
assessment of codes and standards applicable to a nuclear hydrogen plant) way under expected cost. In the $4^{\text {th }}$ quarter, costs are also predicted to be less than anticipated at the INL and ORNL, and so the cost variance will persist and affect the year-end total.

Any money not spent in these controlled work packages will be carried over into FY07 and added to new FY07 work packages at these locations. The addition of new FY07 money to those work packages will be adjusted in regard to the amount being carried over.

Table 2. SI\&SS Controlled Work Packages for FY06

\begin{tabular}{|c|c|c|c|c|c|}
\hline & \multicolumn{4}{|c|}{ Fiscal Quarter } & \multirow[b]{2}{*}{ Totals } \\
\hline & $1^{\text {st }}$ & $2^{\text {nd }}$ & $3^{\text {rd }}$ & $4^{\mathrm{th}^{*}}$ & \\
\hline \multicolumn{6}{|l|}{ ANL (CH16SS01, \$194,611) } \\
\hline BCWS & 11,380 & 41,429 & 42,623 & 57,000 & 152,432 \\
\hline BCWP & 12,518 & 32,979 & 69,057 & 37,878 & 152,432 \\
\hline ACWP & 12,518 & 32,979 & 69,057 & 37,878 & 152,432 \\
\hline SV\% & 0 & -20 & 62 & -34 & 0 \\
\hline $\mathrm{CV} \%$ & 0 & 0 & 0 & 0 & 0 \\
\hline \multicolumn{6}{|l|}{$\begin{array}{l}\text { INL (ID16SS11, ID16SS12, } \\
\$ 849,474)\end{array}$} \\
\hline BCWS & 105,481 & 220,641 & 269,032 & 254,320 & 849,474 \\
\hline BCWP & 99,572 & 204,022 & 294,734 & 251,146 & 849,474 \\
\hline ACWP & 106,583 & 210,141 & 214,151 & 228,599 & 759,474 \\
\hline SV\% & -6 & -8 & 10 & -1 & 0 \\
\hline $\mathrm{CV} \%$ & -7 & -3 & 27 & 9 & 11 \\
\hline \multicolumn{6}{|l|}{$\begin{array}{l}\text { ORNL (OR16SS11, } \\
\$ 100,000)\end{array}$} \\
\hline BCWS & 0 & 0 & 20,000 & 80,000 & 100,000 \\
\hline BCWP & 0 & 0 & 14,000 & 86,000 & 100,000 \\
\hline ACWP & 0 & 0 & 13,969 & 78,000 & 91,936 \\
\hline SV\% & 0 & 0 & -30 & 8 & 0 \\
\hline $\mathrm{CV} \%$ & 0 & 0 & 0 & 9 & 8 \\
\hline \multicolumn{6}{|l|}{ Overall Performance } \\
\hline BCWS & 116,861 & 262,070 & 331,655 & 391,320 & $1,101,906$ \\
\hline BCWP & 112,090 & 237,001 & 377,791 & 375,024 & $1,101,906$ \\
\hline ACWP & 119,101 & 243,120 & 297,177 & 344,477 & $1,003,875$ \\
\hline SV\% & -4 & -10 & 14 & -4 & 0 \\
\hline CV\% & -6 & -3 & 21 & 8 & 9 \\
\hline
\end{tabular}

The PICS figures for the general work packages that were not controlled work packages are shown in Table 3. Actual numbers are provided for the first three quarters, and projected numbers are provided for the 4th quarter since PICS information for September will not be available until October 2006. 
Table 3. SI\&SS General Work Packages for FY06

\begin{tabular}{|c|c|c|c|c|c|}
\hline & \multicolumn{4}{|c|}{ Fiscal Quarter } & \multirow[b]{2}{*}{ Totals } \\
\hline & $1^{\mathrm{st}}$ & $2^{\text {nd }}$ & $3^{\text {rd }}$ & $4^{\mathrm{th}^{*}}$ & \\
\hline \multicolumn{6}{|l|}{$\begin{array}{l}\text { UNLV (ID06SS11, } \\
\$ 2,443,000)\end{array}$} \\
\hline BCWS & 433,622 & 517,007 & 531,888 & 600,483 & $2,083,000$ \\
\hline BCWP & 433,622 & 449,121 & 257,098 & 339,159 & $1,479,000$ \\
\hline ACWP & 330,853 & 257,108 & 282,349 & 308,690 & $1,179,000$ \\
\hline SV\% & 0 & -13 & -52 & -44 & -29 \\
\hline $\mathrm{CV} \%$ & 24 & 43 & -10 & 9 & 20 \\
\hline \multicolumn{6}{|l|}{$\begin{array}{l}\text { UC - Berkeley (ID06SS12, } \\
\$ 191,000)\end{array}$} \\
\hline BCWS & 31,834 & 47,751 & 47,750 & 63,665 & 191,000 \\
\hline BCWP & 31,834 & 41,834 & 45,551 & 1,781 & 121,000 \\
\hline ACWP & 22,927 & 38,760 & 58,000 & 1,313 & 121,000 \\
\hline SV\% & 0 & -12 & -5 & -97 & -37 \\
\hline $\mathrm{CV} \%$ & 28 & 7 & -27 & 26 & 0 \\
\hline \multicolumn{6}{|l|}{ MIT (ID06SS13, \$220,000) } \\
\hline BCWS & 72,601 & 37,399 & 54,900 & 55,100 & 220,000 \\
\hline BCWP & 72,601 & 37,399 & 33,300 & 10,000 & 153,300 \\
\hline ACWP & 33,419 & 52,842 & 25,848 & 10,000 & 122,109 \\
\hline SV\% & 0 & 0 & -39 & -82 & -30 \\
\hline $\mathrm{CV} \%$ & 53 & -41 & 22 & 0 & 20 \\
\hline \multicolumn{6}{|l|}{$\begin{array}{l}\text { General Atomics (ID06SS14, } \\
\$ 616,000 \text { ) }\end{array}$} \\
\hline BCWS & 150,000 & 155,100 & 155,100 & 155,800 & 616,000 \\
\hline BCWP & 135,700 & 117,500 & 95,000 & 132,800 & 481,000 \\
\hline ACWP & 135,700 & 117,500 & 91,100 & 136,700 & 481,000 \\
\hline $\mathrm{SV} \%$ & -10 & -24 & -39 & -15 & -22 \\
\hline $\mathrm{CV} \%$ & 0 & 0 & 4 & -3 & 0 \\
\hline \multicolumn{6}{|l|}{$\begin{array}{l}\text { Ceramatec (ID06SS15, } \\
\$ 300,000)\end{array}$} \\
\hline BCWS & 64,700 & 65,300 & 84,000 & 86,000 & 300,000 \\
\hline BCWP & 60,930 & 83,927 & 75,660 & 79,483 & 300,000 \\
\hline ACWP & 60,930 & 95,324 & 64,263 & 77,483 & 298,000 \\
\hline SV\% & -6 & 29 & -10 & -8 & 0 \\
\hline $\mathrm{CV} \%$ & 0 & -12 & 15 & 3 & 1 \\
\hline \multicolumn{6}{|l|}{ Overall Performance } \\
\hline BCWS & 752,757 & 822,557 & 873,638 & 961,048 & $3,410,000$ \\
\hline BCWP & 734,687 & 729,781 & 506,609 & 563,223 & $2,534,300$ \\
\hline ACWP & 583,829 & 561,534 & 521,560 & 534,186 & $2,201,109$ \\
\hline SV\% & -2 & -11 & -42 & -41 & -26 \\
\hline $\mathrm{CV} \%$ & 21 & 23 & -3 & 5 & 13 \\
\hline
\end{tabular}

$* 4^{\text {th }}$ quarter is projected 
According to Table 3, the general work packages originating from the University of Nevada Las Vegas will complete the year with a negative schedule variance and a positive cost variance. The delays in schedule and spending were caused by several factors. First, the funding for UNLV and its sub-contractors was divided into two portions - FY05 carryover, and FY06 funds. The amount of money left over from FY05 was sufficient to sustain the planned spending rate through March 2006, and after that, FY06 money was supposed to be available. This assumption turned out to be incorrect and the FY06 money did not become available until the summer of FY06. Consequently, work was delayed or slowed at General Atomics, MIT, and UNLV. Second, equipment problems occurred at UNLV that prevented the performance of many materials-related experiments for most of the year. Lastly, there were delays in executing a contract with a sub-contractor at UC-Berkeley, which will prevent the completion of some of the assigned work tasks by the end of FY06.

Due to the delays listed above, General Atomics, MIT, UC-Berkeley, and UNLV have elected to carry over some FY06 work scope and funding into FY07. Items not completed in FY06 will be completed in the first half of FY07 and FY06 carryover money will be used to pay for the work. New FY07 work packages containing only the FY06 carryover items and funding will be written and used to track the performance of this carryover work. Results will be available on PICS. 


\section{ACCOMPLISHMENT HIGHLIGHTS}

The accomplishments described here are organized by work package. The work accomplished under the controlled work packages will be covered first, followed by descriptions of the work accomplished under the general work packages. Greater detail on any one project can be found by examining the reports and documents that were generated by the individual work packages.

\subsection{Controlled Work Packages}

\section{CH16SS11 - NHI System Interface and Support Systems, HyPEP Development}

This work package was managed by Rick Vilim of Argonne National Laboratory.

Under this work package, Argonne was tasked with assisting the Idaho National Laboratory in the development of HyPEP, a software package being developed jointly with the Korea Atomic Energy Research Institute (KAERI) for use in calculating the efficiencies of various combined nuclear plant/hydrogen plant facilities. The software will be capable of calculating the electrical generation efficiencies of a Brayton or Rankine cycle, and the hydrogen production efficiencies of the high-temperature electrolysis and Sulfur-Iodine processes.

In October 2005, Rick Vilim met with Chang Oh, Cliff Davis, and Steve Sherman of the Idaho National Laboratory, and W.J. Lee and Y.J. Lee of KAERI at the INL to discuss the I-NERI collaboration. Project timelines and work goals were discussed, and agreement was reached on the roles and responsibilities of the participants.

In February 2006, Rick Vilim co-authored a report with C. Oh, C. Davis, and S. Sherman that 1) selected a reference design for the nuclear reactor, energy conversion unit, and hydrogen plant; 2) identified key requirements and assumptions for the modeling work; 3 ) defined modeling methods; and 4) provided KAERI collaborators with detailed models of system components such as heat exchangers and other appropriate heat transfer correlations to assist them in HyPEP software development (C.H. Oh, C.B. Davis, S.R. Sherman, R. Vilim, "Development of HyPEP, A Hydrogen Production Plant Efficiency Calculation Program," white paper, February 2006).

In March 2006, a down-select was made to use the GAS-PASS/H code for the high-temperature gas-cooled reactor, and to use the most recent flow sheet available for high temperature electrolysis as the reference process for the hydrogen production plant. Detailed modeling work involving the Sulfur-Iodine process was delayed because the reference flow sheet for that process is still in flux and there is only incomplete data available on the reaction kinetics. Kinetics data are not needed for an equilibrium model like HyPEP, but are needed for working on problems related to transient behaviors. Models for transient behaviors will be developed in FY07 and FY08 and may or may not be included in later versions of HyPEP. 
In May 2006, Rick attended a meeting in South Korea with Chang Oh to discuss HyPEP development at KAERI.

In the summer of 2006, the GAS-PASS/H code was upgraded to handle more complex heat transfer behaviors, and a detailed model of the high-temperature electrolysis cell was developed and benchmarked against other models developed by Carl Stoots and Jim O-Brien of the INL for high-temperature electrolysis cells. Rick's model compares well with those established codes and will be incorporated into HyPEP's reference case.

Rick Vilim is a co-author on the joint year-end report "Summary of HyPEP Simulation Software Activities" with the INL.

\section{ID16SS11 - NHI System Interface and Support Systems Work at the INL}

This work package was managed by Charles Park of the Idaho National Laboratory.

Work in this work package involved six major tasks. These tasks were 1) Begin development of HyPEP simulation software in conjunction with ANL and in support of the I-NERI agreement with KAERI, 2) Update the Balance-of-Plant (BOP) requirements report to include details of the Sulfur-Iodine and high-temperature electrolysis processes, 3) Revise FY05's report on minimum plant spacing requirements, 4) Summarize codes and standards applicable to a nuclear hydrogen plant, 5) Continue to support a general exchange of technological information on connection technologies with the Commisariat à l'Energie Atomique (CEA) under an existing I-NERI agreement, and 6) Assist Oak Ridge National Laboratory in the development of a Materials and Components Test Plan for the DOE NHI. The progress of work in each task is described separately.

\section{HyPEP Development:}

The INL hosted a meeting between HyPEP researchers from ANL, INL, and KAERI in October 2006. In February, the INL and ANL produced a white paper describing the reference case, requirements and assumptions, modeling methods, and other information for HyPEP (see CH16SS11 for more details).

In May 2006, Chang Oh attended a meeting with Rick Vilim at KAERI in Korea to discuss HyPEP development work. At this meeting Chang Oh presented the first integrated model that includes all the components of the primary loop, power conversion unit, intermediate heat transfer loop, and a high-temperature steam electrolysis plant.

In June 2006, the methodology for qualifying integrated steady-state models against established benchmarks was decided. This methodology will be used in FY07 to "debug" an alpha version of HyPEP that is expected to be available by October 2006. 
Chang Oh, Cliff Davis, and Steve Sherman are co-authors on a joint year-end report with ANL titled "Summary of HyPEP Simulation Software Activities."

BOP Requirements Report:

In April, the Level 3 report INL/EXT-06-11232, "Balance of Plant Requirements for a Nuclear Hydrogen Plant", B. Ward, April 2006, was completed. This report describes the requirements for the components and systems that support the hydrogen production portion of a $600 \mathrm{MWth}$ NGNP. These systems, defined as the "balance-ofplant" (BOP), are essential to operate an effective hydrogen production plant. The requirements in this document are applicable to the two baseline process currently under consideration -- S-I, and HTE.

Plant Spacing Report:

The Level 2 milestone "Revise nuclear plant/hydrogen plant spacing requirements to address reviewer's comments." was met on 7/31/2006. A revision of the original report has been provided as the deliverable. In FY05, the document INL/EXT-05-00137, "An Engineering Analysis for Separation Requirements of a Hydrogen Production Plant and High Temperature Nuclear Reactor", Revision 0, was issued. This document provided an analysis of the minimum separation requirements between a nuclear plant and an S-I hydrogen production plant based upon probabilistic risk assessment (PRA) arguments. Revision 1 examined the risk assessment models in more detail and incorporated chemical plant accident information into the models for the Sulfur-Iodine plant.

Assessment of Codes and Standards:

In June 2006, the INL completed a Level 2 milestone to provide a summary report of codes and standards applicable to a nuclear-powered hydrogen plant. The report is titled INL/EXT-06-11482, "Assessment of Codes and Standards Applicable to a Hydrogen Production Plant Coupled to a Nuclear Reactor", by M. Russel. The report showed that there are many non-nuclear codes and standards to consider when constructing a nuclear hydrogen plant, and that a more thorough examination of these codes and standards will be needed when the detailed design work begins on the plant(s).

\section{Support of CEA I-NERI Agreement:}

Steve Sherman and Charles Park met with Dominique Barbier and other CEA representatives at UNLV to discuss the ongoing I-NERI agreement. At this meeting it was agreed that the I-NERI agreement would be revised to focus on specific issues related to high-temperature heat exchanger development, molten salt work, and safety analyses. On-going exchange of technical information since this meeting has been underway.

NHI Materials and Components Test Plan: 
In June 2006, the INL began working with Oak Ridge National Laboratory to develop an NHI Materials and Components Test Plan. This materials and components test plan would be used to organize the development and assessment of individual components for use in nuclear hydrogen systems, so that development and technology decision processes are uniform. A first draft of the Plan will be available at the end of the fiscal year.

\section{$\underline{\text { ID16SS12 - NHI Systems Interface and Support Systems Technical Director }}$}

Steven Sherman of the Idaho National Laboratory is responsible for this work package. The technical director is generally responsible for program planning and project tracking activities, and for coordinating the research efforts of all parties involved in the relevant research areas.

In this capacity, Steve Sherman worked closely with the UNLV High Temperature Heat Exchanger project and attended the UNLV consortium quarterly meetings. Steve also attended the Fall and Spring AIChE Annual Meetings in the capacity of chair and co-chair of selected technical sessions concerning high temperature materials and systems for hydrogen production.

Steve Sherman provided nuclear hydrogen projects to two summer students. The first project concerned the development of a conceptual design for a high-temperature lab-scale closed sulfuric acid loop. The second project entailed an examination of multilayer insulation schemes for long-distance high-temperature heat transport pipes.

OR16SS11 - NHI Materials and Components Test Plan

Dane Wilson is the principal investigator on this work package.

Oak Ridge National Laboratory is serving as lead editor for the development of the NHI Materials and Components Test Plan. Work on the Plan began in June, and a first draft is expected to be completed by the end of the fiscal year. This work is being performed with the help of the Idaho National Laboratory.

\subsection{General Work Packages}

\section{ID06SS11 - UNLVRF High Temperature Heat Exchanger Project}

Tony Hechanova of the University of Nevada Las Vegas is the technical contact for this work package.

Work at UNLV focused on the measurement of materials properties, the study of corrosion layers on materials exposed under Sulfur-Iodine Process conditions, the modeling of compact heat exchanger channels, and the construction and operation of laboratory experiments that simulate compact heat exchanger flow channels. 
In March 2006, tensile testing of Alloys C-22, C-276, 800H, and Waspaloy were completed up to $1000{ }^{\circ} \mathrm{C}$. It was determined that the metallic alloys studied could not be used as structural load-bearing materials above $900{ }^{\circ} \mathrm{C}$. Below $900{ }^{\circ} \mathrm{C}$, Alloy $800 \mathrm{H}$ is the best candidate of those tested. Tensile testing of Alloy 617 and Alloy 718 are underway. Stress corrosion cracking tests involving exposure of these alloys to aqueous sulfuric acid solutions is underway.

Ongoing analysis and optimization is underway of Ceramatec's ceramic compact sulfuric acid decomposer module using Fluent 6.2. The extent of chemical reaction, mechanical and thermal stresses, and material flow rates are being determined as a function of theoretical platinum loading, pressure, friction factors, channel dimensions, and other parameters. Analysis and optimization of a non-catalytic off-set strip fin ceramic heat exchanger and analysis of a Heatric-type metallic heat exchanger is also underway.

An experimental facility for testing mock-up compact heat exchanger flow channels using air and water as the transport fluids has been constructed, and initial testing of Plexiglas models is underway. Similarity in fluid flow conditions is sought (Re, Pr, etc.) between water or air flowing at near room temperature and molten salts or helium flowing at higher temperatures. Data from these experiments will be used to adjust the computer models.

XPS and SEM are being used to support materials corrosion studies that are being conducted at Ceramatec, General Atomics, and UNLV. These techniques are being used to study the thickness, composition, and durability of corrosion layers on selected samples in order to gain a better understanding of which materials are the best candidates to resist corrosive damage in the extreme chemical environments experienced in the Sulfur-Iodine process.

The results of these work tasks for FY06 will be detailed in UNLV's "High Temperature Heat Exchanger Project Annual Report", due to be issued by UNLV at the end of FY06.

\section{ID06SS12 - Materials Design and Modeling for C SiC Ceramic Heat Exchangers}

This work package was managed by Tony Hechanova of UNLV while the work was performed by Dr. Per Peterson and his group at the University of California -Berkeley.

Work in this work package included identification and optimization of optimized candidate ceramic heat exchanger materials and fabrication methods, studies of helium permeation through $\mathrm{C} / \mathrm{SiC}$ materials derived from low-cost chopped-carbon fiber reinforced silicon carbide, examination of CVD coatings and coating techniques to decrease permeability, heat exchanger design calculations, and safety studies related to $\mathrm{C} / \mathrm{SiC}$ heat exchangers. 
$\mathrm{C} / \mathrm{SiC}$ heat exchanger plates were manufactured using Teflon molds. The Teflon molds allowed for the formation of features as fine as $1.5 \mathrm{~mm}$ in width and produced plates with very few visible defects and low porosity. A sub-contract with COI was secured for continued manufacturing of plate samples.

Permeability testing of the plates with high temperature helium proved that CVD coatings of graphite or other materials are needed to reduce helium porosity to acceptable levels with this material.

In the modeling work, 2-D heat and mass transfer models were found to be inadequate for modeling compact heat exchangers composed of the $\mathrm{C} / \mathrm{SiC}$ material and work is being performed to develop 3-D porous media to be used instead.

Laboratory experiments to determine the solubility limit of sodium metal in FLiNaK liquid salt were performed. Early tests showed a measurable amount of sodium and potassium metal dissolved into the salt upon contact, but the analytical techniques used for these tests were not precise enough to define a solubility limit.

Due to the late arrival of FY06 funds at UC-Berkeley, the safety analysis work will be delayed until the first half of FY07.

The results of this work will be published in the UNLV "High Temperature Heat Exchanger Project Annual Report", due to be issued by UNLV at the end of FY06.

\section{$\underline{\text { ID06SS13 - Pt Added Alloy Catalysts }}$}

This work package was managed by Tony Hechanova of UNLV while the work was performed by Dr. Ron Ballinger and his group at the Massachusetts Institute of Technology.

The tasks assigned in this work package include completion of construction of a catalyst effectiveness testing system that was started in FY05, procurement of two large heats (approx. $50 \mathrm{~kg}$ each) of Alloy 800 and 617 plus 1-2 wt\% Pt, measurement of the catalytic ability of the test materials, and design of a Heatric-style compact heat exchanger made of the test materials.

The catalyst effectiveness testing system, consisting of a tube furnace test chamber and a gas chromatograph, was assembled and calibrated using known mixtures of $\mathrm{SO}_{2}$ and $\mathrm{O}_{2}$. Testing of ribbon material obtained from small batches of alloys containing 2 to $5 \mathrm{wt} \% \mathrm{Pt}$ showed definite catalytic activity versus control samples having no platinum present. The next step in these measurements is to determine the catalytic effectiveness and catalytic stability of the material in comparison to titania-supported platinum catalyst particles reacting under the same conditions.

Delays in receiving a portion of FY06 funds prevented the procurement of the larger heats of materials until July 2006. Now, due to changes in direction, production of 
the larger heats of material will not be pursued, and the money saved by not ordering the larger heats will be invested to perform more catalyst tests on existing materials.

Detailed designs of a Heatric-style compact metallic heat exchanger using the Ptcontaining alloys were generated. Due to changes in direction, the heat exchanger will not be manufactured, but the designs will be saved for future use.

Final results from the catalyst testing work and other items will be provided in UNLV's "High Temperature Heat Exchanger Project Annual Report", due to be issued by UNLV at the end of FY06.

ID06SS14 - Corrosion and Crack Growth Studies of Materials in HIx Environment as Functions of Metallurgical Variables and Thermochemical Treatment of Materials

This work package was managed by Tony Hechanova of UNLV while the work was performed by Bunsen Wong, Gottfried Besenbruch, and others at General Atomics.

General Atomic's main tasks in this work package were to perform corrosion testing of materials exposed to the chemical environments typical of the $\mathrm{HI} / \mathrm{H} 2 \mathrm{O}$ purification section of the Sulfur-Iodine process. General Atomics exposed unstressed and stressed materials samples to these chemical environments over defined time periods and examined the results.

Distinct chemical environments were examined - boiling concentrated phosphoric acid with and without $\mathrm{HI}$ contamination, $\mathrm{HI} / \mathrm{I}_{2} / \mathrm{H}_{2} \mathrm{O}$ mixtures with and without trace sulfuric acid contamination, gaseous $\mathrm{HI}$, and condensing $\mathrm{I}_{2}$. Good materials candidates for boiling concentrated phosphoric acid with or without contamination include Ta-2.5W, Ta-10W, Ag, C-706 (Cu-Ni), and SiSiC composite. For $\mathrm{HI} / \mathrm{I}_{2} / \mathrm{H}_{2} \mathrm{O}$ mixtures, Ta and Ta$10 \mathrm{~W}$ appear to be the best candidate materials. In gaseous $\mathrm{HI}$ and condensing $\mathrm{I}_{2}$ environments, Hastelloy B2 has been shown to work well. All successful candidate materials underwent hundreds of hours of exposure without significant corrosion.

Future corrosion testing will involve exposure of these materials in the form of cladded samples and in flowing environments.

Final results from these corrosion tests will be provided in UNLV's "High Temperature Heat Exchanger Project Annual Report", due to be issued by UNLV at the end of FY06.

ID06SS15 - Ceramic Heat Exchanger Development for Application to NHI Hydrogen Production Processes

This work package was managed by Tony Hechanova of UNLV while the work was performed by Merrill Wilson and others at Ceramatec, Inc. 
The work in this work package was divided into three tasks. First, ceramic materials were examined and characterized for use in the sulfuric acid decomposition step of the Sulfur-Iodine process. Second, ceramic heat exchanger designs were pursued for the same purpose. Third, materials suitable for use in high-temperature oxygen coolers were examined.

Corrosion testing of $\mathrm{SiC}$ and $\mathrm{Si}_{3} \mathrm{~N}_{4}$ materials showed that both materials are very good candidates use in sulfuric acid decomposers. After exposure of these materials to a mixture of $60 \%$ water, $30 \%$ sulfuric acid, $8 \%$ nitrogen, and $2 \%$ oxygen at $900{ }^{\circ} \mathrm{C}$ for 1000 hours, samples were analyzed mechanically and by SEM/XPS. Both materials showed a slight increase in mechanical strength after exposure. A micro-examination of the sample surfaces showed the formation of a thin layer of $\mathrm{SiO}_{2}$ on exposed surfaces. This surface layer of $\mathrm{SiO}_{2}$, it was speculated, helped seal surface defects, which served to increase the average strength of the materials.

Ceramatec numerical models of their ceramic compact sulfuric acid decomposer design were compared to models developed at UNLV, and the models were found to be in general agreement to within 5\% for known cases.

As an aside, technology for sealing ceramic materials to metal materials was examined. Metal/ceramic seals were formed and tested for permeability. The permeability of the test specimens showed a leak rate of $0.2 \mathrm{~cm}^{3} / \mathrm{min}$ at a pressure difference of $1 \mathrm{~atm}$. This leak rate is still excessive, and more work will be done in FY07 to improve sealing techniques and reduce the leak rate.

In the area of oxygen cooling, a process model has been developed that defines the heat duty of an oxygen cooler for use with high-temperature electrolysis. The waste heat collected from the oxygen chiller can be used to raise the temperature of the incoming feedstock materials for the electrolyzer. Two environmental exposure rigs for exposing candidate materials to hot oxygen environments have been constructed, and material testing is expected to be initiated before the end of the fiscal year.

Final results of Ceramatec's work will be provided in UNLV's 'High Temperature Heat Exchanger Project Annual Report", due to be issued by UNLV at the end of FY06. 


\section{SET OF TECHNICAL ISSUES}

The list of known System Interface and Supporting Systems technical issues is shown in Table 1. This list was adapted from a preliminary list of technical issues listed in Reference 1. The table classifies the technical issues under the areas of materials, mechanical construction (design), balance-of-plant and infrastructure, operation, and safety. Priorities are assessed, and the issues are ranked in accordance to their importance to implementing a pilot-scale or engineering-scale demonstration of the system interface and supporting systems technologies. Priority 1 items must be resolved in order to implement pilot-scale solutions, and Priority 2 items will need to be resolved in order to implement engineering-scale solutions. Priority 3 items are items that do not need to be resolved to enable and engineering-scale demonstration but may affect the eventual success of a commercial-scale installation. It is recognized that the list of technical issues is broad, and that nearly all of the issues listed below can be further sub-divided into more narrowly defined problems.

Table 3. Set of Technical Issues

\begin{tabular}{|c|l|c|}
\hline Number & \multicolumn{1}{|c|}{ Description } & Priority \\
\hline 1. Materials & 1 \\
\hline 1.1 .1 & Choose heat transfer fluid for pilot-scale system interface & 2 \\
\hline 1.1 .2 & $\begin{array}{l}\text { Choose heat transfer fluid for engineering-scale system } \\
\text { interface }\end{array}$ & 1 \\
\hline 1.2 .1 & $\begin{array}{l}\text { Determine materials candidates for all operational units } \\
\text { shown on the latest S-I flow sheet }\end{array}$ & 1 \\
\hline 1.2 .2 & $\begin{array}{l}\text { Determine materials candidates for all operational units } \\
\text { shown on the latest HTE flow sheet }\end{array}$ & 2 \\
\hline 1.2 .3 & $\begin{array}{l}\text { Choose materials for system interface and support systems } \\
\text { pilot-scale equipment }\end{array}$ & 1 \\
\hline 1.2 .4 & $\begin{array}{l}\text { Choose materials for system interface and support systems } \\
\text { engineering-scale equipment }\end{array}$ & 1 \\
\hline 1.3 & Determine corrosion behavior of selected materials & 1 \\
\hline 1.4 & Determine mechanical failure behaviors of selected materials & 2 \\
\hline 1.5 & $\begin{array}{l}\text { Determine manufacturing methods and examine material cost } \\
\text { information }\end{array}$ & 1 \\
\hline 1.6 .1 & Choose insulation materials for pilot-scale equipment & 1 \\
\hline 1.6 .2 & Choose insulation materials for engineering-scale equipment & 2 \\
\hline 2. Mechanical Construction & Design of intermediate or secondary heat exchanger & 1 \\
\hline 2.1 .1 & Design of process heat exchanger for S-I pilot-scale process & $\begin{array}{l}\text { Design of process heat exchanger for S-I engineering-scale } \\
\text { process }\end{array}$ \\
\hline 2.2 .1 & Design of process heat exchanger for HTE pilot-scale process & 1 \\
\hline 2.2 .2 &
\end{tabular}




\begin{tabular}{|c|c|c|}
\hline Number & Description & Priority \\
\hline 2.3 .2 & $\begin{array}{l}\text { Design of process heat exchanger for HTE engineering-scale } \\
\text { process }\end{array}$ & 2 \\
\hline 2.4 & $\begin{array}{l}\text { Design of heat exchanger for alternative hydrogen production } \\
\text { process at applicable scale }\end{array}$ & 2 \\
\hline 2.5 .1 & $\begin{array}{l}\text { Determine intermediate loop configuration and design for } \\
\text { pilot-scale thermal transmission }\end{array}$ & 1 \\
\hline 2.5 .2 & $\begin{array}{l}\text { Determine intermediate loop configuration and design for } \\
\text { engineering-scale thermal transmission. }\end{array}$ & 2 \\
\hline 2.6 & $\begin{array}{l}\text { Determine candidate mechanical designs for unit operation } \\
\text { components on the S-I flow sheet and compare with available } \\
\text { materials choices. }\end{array}$ & 1 \\
\hline 2.7 & Experimental testing of lab-scale heat exchanger prototypes & 1 \\
\hline 2.8 & Experimental testing of pilot-scale heat exchanger prototypes & 1 \\
\hline 2.9 & $\begin{array}{l}\text { Experimental testing of engineering-scale heat exchanger } \\
\text { prototypes }\end{array}$ & 2 \\
\hline 2.10 & Engineering-scale intermediate loop safety assessments & 1 \\
\hline 2.11 & Applicability of modular construction techniques & 3 \\
\hline \multicolumn{3}{|c|}{ 3. Balance-of-Plant and Infrastructure } \\
\hline 3.1 & Define balance-of-plant requirements & 1 \\
\hline 3.2 .1 & $\begin{array}{l}\text { Determine approximate physical layout of S-I plant at various } \\
\text { scales (unit and plant sizing) }\end{array}$ & 1 \\
\hline 3.2 .2 & $\begin{array}{l}\text { Determine approximate physical layout of HTE plant at } \\
\text { various scales (unit and plant sizing) }\end{array}$ & 1 \\
\hline 3.3 .1 & $\begin{array}{l}\text { Design of balance-of-plant configuration for S-I pilot-scale } \\
\text { plant }\end{array}$ & 1 \\
\hline 3.3 .2 & $\begin{array}{l}\text { Design of balance-of-plant configuration for HTE pilot-scale } \\
\text { plant }\end{array}$ & 1 \\
\hline 3.4 .1 & $\begin{array}{l}\text { Determine baseline balance-of-plant configuration for the } \\
\text { engineering-scale S-I plant }\end{array}$ & 2 \\
\hline 3.4 .2 & $\begin{array}{l}\text { Determine baseline balance-of-plant configuration for the } \\
\text { engineering-scale HTE plant }\end{array}$ & 2 \\
\hline 3.5 .1 & Define infrastructure requirements for pilot-scale plants & 1 \\
\hline 3.5 .2 & $\begin{array}{l}\text { Define infrastructure requirements for engineering-scale } \\
\text { plants }\end{array}$ & 2 \\
\hline 3.6 & $\begin{array}{l}\text { Incorporate commercial chemical industry data into balance- } \\
\text { of-plant and infrastructure designs }\end{array}$ & 1 \\
\hline \multicolumn{3}{|c|}{ 4. Operation } \\
\hline 4.1 & $\begin{array}{l}\begin{array}{l}\text { Develop steady-state energy/mass balances for system } \\
\text { interface configurations }\end{array} \\
\end{array}$ & 1 \\
\hline 4.2 & $\begin{array}{l}\text { Develop transient models to understand temperature/pressure } \\
\text { variations during start-up, shutdown, and off-normal } \\
\text { conditions }\end{array}$ & 1 \\
\hline 4.3 & Intermediate loop contamination measurement and control & 2 \\
\hline
\end{tabular}




\begin{tabular}{|c|l|c|}
\hline Number & \multicolumn{1}{|c|}{ Description } & Priority \\
\hline 4.4 .1 & $\begin{array}{l}\text { Develop control system and instrumentation requirements for } \\
\text { pilot-scale S-I plant }\end{array}$ & 1 \\
\hline 4.4 .2 & $\begin{array}{l}\text { Develop control system and instrumentation requirements for } \\
\text { pilot-scale HTE plant }\end{array}$ & 1 \\
\hline 4.5 .1 & $\begin{array}{l}\text { Develop control system and instrumentation requirements for } \\
\text { engineering-scale S-I plant }\end{array}$ & 2 \\
\hline 4.5 .2 & $\begin{array}{l}\text { Develop control system and instrumentation requirements for } \\
\text { engineering-scale HTE plant }\end{array}$ & 2 \\
\hline 4.6 & $\begin{array}{l}\text { Determine need and feasibility of auxiliary heat source and } \\
\text { heat sink for engineering-scale intermediate loop }\end{array}$ & 2 \\
\hline 4.7 & $\begin{array}{l}\text { Demonstrate fully functional pilot-scale intermediate heat } \\
\text { transport loop. }\end{array}$ & 2 \\
\hline 4.8 & $\begin{array}{l}\text { Demonstrate fully functional engineering-scale intermediate } \\
\text { heat transport loop }\end{array}$ & 2 \\
\hline $5.5 a f e t y$ and Environment & $\begin{array}{l}\text { Develop environmental permit documentation, as needed, to } \\
\text { support the pilot-scale plants }\end{array}$ & 1 \\
\hline 5.1 .1 & $\begin{array}{l}\text { Develop environmental permit documentation, as needed, to } \\
\text { support the engineering-scale plants }\end{array}$ & 2 \\
\hline 5.1 .2 & $\begin{array}{l}\text { Determine safety implications of breached process heat } \\
\text { exchanger }\end{array}$ & $\begin{array}{l}\text { Assess existing codes and standards applicable to design and } \\
\text { operation of combined nuclear plant/hydrogen plant facility }\end{array}$ \\
\hline 5.2 & $\begin{array}{l}\text { Determine required nuclear plant/hydrogen plant spacing } \\
\text { requirements }\end{array}$ & 1 \\
\hline 5.3 & Study nuclear plant/hydrogen plant isolation methods & 1 \\
\hline 5.4 &
\end{tabular}




\section{SET OF PROJECTS}

The list of past and on-going System Interface and Supporting Systems projects is shown in Table 2. The table provides the project date, the description, and location for each project. Where reports or documents have been written, report or document titles are provided under the description heading. Where work is underway and reports or project documents have yet to be issues, the work package or NERI project title is provided under the description heading instead. In later versions of this document, this table will be updated to provide report and document titles as they become available.

Table 4. Set of System Interface and Supporting Systems Projects

\begin{tabular}{|l|l|c|c|}
\hline \multicolumn{1}{|c|}{ Identifier } & \multicolumn{1}{|c|}{ Description } & $\begin{array}{c}\text { Project } \\
\text { Date }\end{array}$ & Location \\
\hline $\begin{array}{l}\text { ANL } \\
\text { W7500- } \\
\text { 0001-ES-00 }\end{array}$ & Reactor/Process Interface Requirements & 2004 & ANL-W \\
\hline $\begin{array}{l}\text { ANL } \\
\text { W002-ES-00 }\end{array}$ & $\begin{array}{l}\text { Reactor/Process Interface Heat Exchanger and } \\
\text { Intermediate Loop Technical Issues }\end{array}$ & 2004 & ANL-W \\
\hline $\begin{array}{l}\text { ANL } \\
\text { W7500- } \\
\text { 0003-ES-00 }\end{array}$ & $\begin{array}{l}\text { Balance of Plant Requirements for a Nuclear } \\
\text { Hydrogen Pilot Plant }\end{array}$ & 2004 & ANL-W \\
\hline $\begin{array}{l}\text { INEEL/EXT- } \\
\text { 04-01791 }\end{array}$ & $\begin{array}{l}\text { Infrastructure Requirements for a Nuclear } \\
\text { Hydrogen Pilot Plant }\end{array}$ & 2004 & INEEL \\
\hline $\begin{array}{l}\text { INL/EXT- } \\
\text { 05-00137 }\end{array}$ & $\begin{array}{l}\text { An Engineering Analysis for Separation } \\
\text { Requirements of a Hydrogen Production Plant } \\
\text { and High-Temperature Nuclear Reactor }\end{array}$ & 2005 & INL \\
\hline $\begin{array}{l}\text { INL/EXT- } \\
\text { 05-00453 }\end{array}$ & $\begin{array}{l}\text { Thermal-Hydraulic Analyses of Heat Transfer } \\
\text { Fluid Requirements and Characteristics for } \\
\text { Coupling a Hydrogen Production Plant to a High- } \\
\text { Temperature Nuclear Reactor }\end{array}$ & 2005 & INL \\
\hline $\begin{array}{l}\text { INL/EXT- } \\
\text { 05-00690 }\end{array}$ & $\begin{array}{l}\text { Engineering Analysis of Intermediate Loop and } \\
\text { Process Heat Exchanger Requirements to Include } \\
\text { Configuration Analysis and Materials Needs }\end{array}$ & 2005 & INL \\
\hline ID06SS11a & $\begin{array}{l}\text { Study tensile properties of nickel-based alloys C- } \\
22, \text { C-276, Waspaloy and 800H at temperatures } \\
\text { ranging from ambient to 1000 }{ }^{\circ} \text { C }\end{array}$ & 2006 & UNLV \\
\hline ID06SS11b & $\begin{array}{l}\text { Study corrosion fracture toughness and crack- } \\
\text { growth propagation susceptibility of alloys C-22, } \\
\text { C-276, Waspaloy and 800H at temperatures up to } \\
\text { 450 }{ }^{\circ} \text { C }\end{array}$ & 2006 & UNLV \\
\hline
\end{tabular}




\begin{tabular}{|c|c|c|c|}
\hline Identifier & Description & $\begin{array}{c}\text { Project } \\
\text { Date }\end{array}$ & Location \\
\hline ID06SS11c & $\begin{array}{l}\text { Mechanical and thermal stress analysis of } \\
\text { Ceramatec's sulfuric acid decomposition heat } \\
\text { exchanger design }\end{array}$ & 2006 & UNLV \\
\hline ID06SS11d & $\begin{array}{l}\text { Procurement and construction of HTHX } \\
\text { simulation test equipment and performance of } \\
\text { validation tests }\end{array}$ & 2006 & UNLV \\
\hline ID06SS11e & $\begin{array}{l}\text { Analysis of the structure and composition of } \\
\text { corrosion layers on candidate materials for HIx } \\
\text { process (Ta-2.5W, Nb-10Hf, Nb-1Zr, others) }\end{array}$ & 2006 & UNLV \\
\hline ID06SS12a & $\begin{array}{l}\text { Perform thermal and mechanical stress analysis } \\
\text { of } \mathrm{C} / \mathrm{SiC} \text { heat exchanger plate }\end{array}$ & 2006 & UCB \\
\hline ID06SS12b & $\begin{array}{l}\text { Examine } \mathrm{C} / \mathrm{SiC} \text { composite heat exchanger } \\
\text { fabrication methods }\end{array}$ & 2006 & UCB \\
\hline ID06SS12c & $\begin{array}{l}\text { Analyze } \mathrm{C} / \mathrm{SiC} \text { composite heat exchanger safety } \\
\text { issues related to working with high pressure } \\
\text { helium, liquid salts, and tritium }\end{array}$ & 2006 & UCB \\
\hline ID06SS13a & $\begin{array}{l}\text { Determine catalyst effectiveness of Alloy } \\
617 / 800+\mathrm{Pt} \text { for decomposing } \mathrm{SO}_{3}\end{array}$ & 2006 & MIT \\
\hline ID06SS13b & $\begin{array}{l}\text { Design test article heat exchanger using the Pt- } \\
\text { added alloys }\end{array}$ & 2006 & MIT \\
\hline ID06SS14a & $\begin{array}{l}\text { Install test system for studying corrosion of } \\
\text { samples in HIx extractive distillation } \\
\text { environments }\end{array}$ & 2006 & GA \\
\hline ID06SS14b & $\begin{array}{l}\text { Install crack growth measurement apparatus for } \\
\text { HIx environments }\end{array}$ & 2006 & GA \\
\hline ID06SS14c & $\begin{array}{l}\text { Study corrosion and crack growth of select } \\
\text { samples in HIx extractive distillation } \\
\text { environments }\end{array}$ & 2006 & GA \\
\hline ID06SS15a & $\begin{array}{l}\text { Develop design concepts for oxygen heat } \\
\text { exchanger and oxygen separation systems }\end{array}$ & 2006 & Ceramatec \\
\hline ID06SS15b & $\begin{array}{l}\text { Perform corrosion testing on select materials for } \\
\text { oxygen heat exchange and separation }\end{array}$ & 2006 & Ceramatec \\
\hline ID06SS15c & $\begin{array}{l}\text { Perform materials corrosion testing on select } \\
\text { ceramic materials for S-I sulfuric acid } \\
\text { environments }\end{array}$ & 2006 & Ceramatec \\
\hline ID06SS15d & $\begin{array}{l}\text { Perform analyses with UNLV of thermochemical } \\
\text { performance of proposed Ceramatec heat } \\
\text { exchanger designs. Fabricate components to } \\
\text { assess performance and to validate models. }\end{array}$ & 2006 & Ceramatec \\
\hline CH16SS11 & $\begin{array}{l}\text { NHI Systems Interface and Support Systems - } \\
\text { HyPEP Development }\end{array}$ & 2006 & ANL \\
\hline ID16SS11a & $\begin{array}{l}\text { Revise nuclear plant/hydrogen plant spacing } \\
\text { report to adjust for reviewer's comments }\end{array}$ & 2006 & INL \\
\hline
\end{tabular}




\begin{tabular}{|l|l|c|c|}
\hline \multicolumn{1}{|c|}{ Identifier } & \multicolumn{1}{|c|}{ Description } & $\begin{array}{c}\text { Project } \\
\text { Date }\end{array}$ & Location \\
\hline ID16SS11b & $\begin{array}{l}\text { Assess codes and standards applicable to } \\
\text { combined nuclear plant/hydrogen plant }\end{array}$ & 2006 & INL \\
\hline ID16SS11c & $\begin{array}{l}\text { Revise balance-of-plant requirements to take into } \\
\text { account individual requirements of the S-I and } \\
\text { HTE production processes }\end{array}$ & 2006 & INL \\
\hline ID16SS11d & $\begin{array}{l}\text { Initiate work on HyPEP (Hydrogen Plant } \\
\text { Efficiency program), software that will allow for } \\
\text { simulation of system interface and related } \\
\text { systems }\end{array}$ & 2008 & INL \\
\hline $\begin{array}{l}\text { NERI } \\
\text { 05-154 }\end{array}$ & $\begin{array}{l}\text { "Molten Salt Transport Loop: Materials } \\
\text { Corrosion and Heat Transfer Phenomena" }\end{array}$ & 2005 & U of Wi \\
\hline $\begin{array}{l}\text { NERI } \\
\text { 05-032 }\end{array}$ & $\begin{array}{l}\text { "Silicon Carbide Ceramics for Compact Heat } \\
\text { Exchangers" }\end{array}$ & 2005 & $\begin{array}{c}\text { Johns } \\
\text { Hopkins }\end{array}$ \\
\hline $\begin{array}{l}\text { NERI } \\
\text { 06-024 }\end{array}$ & $\begin{array}{l}\text { "Ni-Si Alloys for the S-I Reactor-Hydrogen } \\
\text { Production Process Interface" }\end{array}$ & 2006 & U of Mo \\
\hline $\begin{array}{l}\text { NERI } \\
06-041\end{array}$ & $\begin{array}{l}\text { "Dynamic Simulation and Optimization of } \\
\text { Nuclear Hydrogen Production Systems" }\end{array}$ & 2006 & MIT \\
\hline $\begin{array}{l}\text { NERI } \\
\text { 06-060 }\end{array}$ & $\begin{array}{l}\text { "Development of Efficient Flowsheet and } \\
\text { Transient Modeling for Nuclear Heat Coupled } \\
\text { Sulfur Iodine Cycle for Hydrogen Production" }\end{array}$ & 2006 & $\begin{array}{c}\text { U of } \\
\text { Purdue }\end{array}$ \\
\hline
\end{tabular}

Table 3 shows projects in the thermochemical and high temperature electrolysis areas that have some influence on the solutions to the System Interface and Support Systems technical issues. These projects will also be referenced in the map. Once again, where reports and documents are not yet available, the work package title or NERI project title is provided instead under the description heading. In later versions of this document, this table will be updated to include document or report titles as they become available.

Table 5. Set of Relevant Thermochemical and HTE Projects

\begin{tabular}{|l|l|c|c|}
\hline \multicolumn{1}{|c|}{ Identifier } & \multicolumn{1}{|c|}{ Description } & $\begin{array}{c}\text { End } \\
\text { Date }\end{array}$ & Location \\
\hline Thermochemical & 2005 & SRNL \\
\hline $\begin{array}{l}\text { NERI 02- } \\
160\end{array}$ & $\begin{array}{l}\text { Centralized Hydrogen Production from Nuclear } \\
\text { Power: Infrastructure Analysis and Test-Case } \\
\text { Design Study }\end{array}$ & 2006 & SNL \\
\hline AL16TC23 & $\begin{array}{l}\text { Integrated Lab Scale Experiment Facility } \\
\text { Preparation }\end{array}$ & 2006 & GA \\
\hline AL16TC25 & $\begin{array}{l}\text { GA Integrated Lab Scale Experiment Integration } \\
\text { Activities }\end{array}$ & 2006 & ANL \\
\hline CH16TC31 & Calcium Bromine Cycles & INL \\
\hline High Temperature Electrolysis & High Temperature Electrolysis System Definition & 2006 & ID16EL11 \\
\hline
\end{tabular}




\section{MAPPING OF PROJECTS TO TECHNICAL ISSUES}

Table 4 shows the mapping of projects to technical issues. The project identifiers are the same ones used in Tables 2 and 3 to differentiate between projects. If the project identifier box is empty in Table 4, then no projects have yet been pursued to solve the technical issue. The "Resolved?" indicator shows whether the technical issue has been resolved or will be resolved this fiscal year. The "Year Needed" column shows when the particular technical issue must be solved in order to support the construction and operation of pilot-scale and engineering-scale equipment. If the "Year Needed" box is filled with an "as needed" indicator, then the work is expected to be ongoing and does not have a defined resolution.

Table 6. Map of Projects and Issues

\begin{tabular}{|c|l|c|c|}
\hline $\begin{array}{c}\text { Issue } \\
\text { Number }\end{array}$ & \multicolumn{1}{|c|}{ Project Identifier } & Resolved? & $\begin{array}{c}\text { Year } \\
\text { Needed }\end{array}$ \\
\hline 1. Materials & \multicolumn{3}{|c|}{2009} \\
\hline 1.1 .1 & $\begin{array}{l}\text { ANL W7500-0002-ES-00, INL/EXT-05-00137, } \\
\text { INL/EXT-05-00453, INL/EXT-05-00690, } \\
\text { ID06SS12c, ID16SS11a, NERI 05-154 }\end{array}$ & No & \\
\hline 1.1 .2 & $\begin{array}{l}\text { ANL W7500-0002-ES-00, INL/EXT-05-00137, } \\
\text { INL/EXT-05-00453, INL/EXT-05-00690, } \\
\text { ID06SS12c, ID16SS11a, NERI 05-154 }\end{array}$ & No & 2014 \\
\hline 1.2 .1 & $\begin{array}{l}\text { ANL W7500-0003-ES-00, ID06SS11a, } \\
\text { ID06SS11b, ID06SS11e, ID06SS14a, } \\
\text { ID06SS14b, ID06SS14c, ID06SS15c, NERI 06- } \\
\text { 024 }\end{array}$ & No & 2007 \\
\hline 1.2 .2 & $\begin{array}{l}\text { ANL W7500-0003-ES-00, ID06SS11a, } \\
\text { ID06SS15b }\end{array}$ & No & 2007 \\
\hline 1.2 .3 & $\begin{array}{l}\text { ANL W7500-0003-ES-00, INL/EXT-05-00453, } \\
\text { INL/EXT-05-00690, ID06SS11a, ID06SS11b, } \\
\text { ID06SS11e, ID06SS12c, ID06SS14a, ID06SS14b, } \\
\text { ID06SS14c, ID06SS15b, ID06SS15c, NERI 06- } \\
\text { 024 }\end{array}$ & No & 2010 \\
\hline 1.2 .4 & $\begin{array}{l}\text { ANL W7500-0003-ES-00, INL/EXT-05-00453, } \\
\text { INL/EXT-05-00690, ID06SS11a, ID06SS11b, } \\
\text { ID06SS11e, ID06SS12c, ID06SS14a, ID06SS14b, } \\
\text { ID06SS14c, ID06SS15b, ID06SS15c, NERI 06- } \\
\text { 024 }\end{array}$ & No & 2015 \\
\hline $\begin{array}{l}\text { ID06SS11b, ID06SS11e, ID06SS14a, } \\
\text { ID06SS14b, ID06SS14c, ID06SS15b, } \\
\text { ID06SS15c, NERI 05-154, NERI 06-024 }\end{array}$ & No & $\begin{array}{c}\text { As } \\
\text { needed }\end{array}$ \\
\hline $\begin{array}{l}\text { INL/EXT-05-00453, INL/EXT-05-00690, } \\
\text { ID06SS11a, ID06SS11b, ID06SS11c, ID06SS12a, } \\
\text { ID06SS14b, ID06SS14c, ID06SS15d }\end{array}$ & No & As \\
\hline 1.3 & & \\
\hline & & & \\
\hline
\end{tabular}




\begin{tabular}{|c|c|c|c|}
\hline $\begin{array}{l}\text { Issue } \\
\text { Number }\end{array}$ & Project Identifier & Resolved? & $\begin{array}{l}\text { Year } \\
\text { Needed }\end{array}$ \\
\hline 1.5 & $\begin{array}{l}\text { ID06SS12b, ID06SS13b, ID06SS15d, NERI 05- } \\
032\end{array}$ & No & $\begin{array}{c}\text { As } \\
\text { needed }\end{array}$ \\
\hline 1.6 .1 & $\begin{array}{l}\text { ANL W7500-0002-ES-00, INL/EXT-05-00453, } \\
\text { INL/EXT-05-00690 }\end{array}$ & No & 2010 \\
\hline 1.6 .2 & $\begin{array}{l}\text { ANL W7500-0002-ES-00, INL/EXT-05-00453, } \\
\text { INL/EXT-05-00690 }\end{array}$ & No & 2015 \\
\hline \multicolumn{4}{|c|}{ 2. Mechanical Construction } \\
\hline 2.1 .1 & $\begin{array}{l}\text { ANL W7500-0003-ES-00, INL/EXT-05-00453, } \\
\text { INL/EXT-05-00690, ID16SS12a }\end{array}$ & No & 2010 \\
\hline 2.2 .1 & $\begin{array}{l}\text { INL/EXT-05-00453, INL/EXT-05-00690, } \\
\text { ID06SS11c, ID06SS13b, ID06SS15d }\end{array}$ & No & 2010 \\
\hline 2.2 .2 & $\begin{array}{l}\text { INL/EXT-05-00453, INL/EXT-05-00690, } \\
\text { ID06SS11c, ID06SS13b, ID06SS15d }\end{array}$ & No & 2015 \\
\hline 2.3 .1 & & No & 2009 \\
\hline 2.3 .2 & & No & 2015 \\
\hline 2.4 & & No & 2010 \\
\hline 2.5 .1 & INL/EXT-05-00453 & No & 2009 \\
\hline 2.5 .2 & INL/EXT-05-00453 & No & 2015 \\
\hline 2.6 & $\begin{array}{l}\text { INL/EXT-05-00453, INL/EXT-05-00690, } \\
\text { ID06SS11c, ID06SS13b, ID06SS15a, ID06SS15d }\end{array}$ & No & 2007 \\
\hline 2.7 & ID06SS11d & No & 2009 \\
\hline 2.8 & & No & 2013 \\
\hline 2.9 & & No & 2015 \\
\hline 2.10 & $\begin{array}{l}\text { ANL W7500-0002-ES-00, INL/EXT-05-00137, } \\
\text { ID06SS12c, ID16SS11a }\end{array}$ & No & 2013 \\
\hline 2.11 & ANL W7500-0002-ES-00 & No & 2019 \\
\hline \multicolumn{4}{|c|}{ 3. Balance of Plant and Infrastructure } \\
\hline 3.1 & ANL W7500-0001-ES-00, ID16SS11c & Yes & 2006 \\
\hline 3.2 .1 & $\begin{array}{l}\text { NERI 02-160, INEEL/EXT-04-01791, } \\
\text { AL16TC23, ID16SS11c }\end{array}$ & No & 2008 \\
\hline 3.2 .2 & INEEL/EXT-04-01791, ID16EL11 & No & 2008 \\
\hline 3.3 .1 & NERI 02-160, AL16TC25, ID16SS11c & No & 2008 \\
\hline 3.3 .2 & ID16SS11c, ID16EL11 & No & 2008 \\
\hline 3.4 .1 & & No & 2013 \\
\hline 3.4 .2 & & No & 2013 \\
\hline 3.5 .1 & INEEL/EXT-04-01791 & No & 2008 \\
\hline 3.5 .2 & & No & 2013 \\
\hline 3.6 & ID06SS11a, ID06SS11b & No & 2008 \\
\hline \multicolumn{4}{|c|}{ 4. Operation } \\
\hline 4.1 & INL/EXT-05-00453, ID06SS11d, CH16SS11 & Yes & 2006 \\
\hline 4.2 & ID06SS11d, CH16SS11, NERI 06-041, NERI 06- & No & 2008 \\
\hline
\end{tabular}




\begin{tabular}{|c|c|c|c|}
\hline $\begin{array}{l}\text { Issue } \\
\text { Number }\end{array}$ & Project Identifier & Resolved? & $\begin{array}{c}\text { Year } \\
\text { Needed }\end{array}$ \\
\hline & 060 & & \\
\hline 4.3 & & No & 2013 \\
\hline 4.4 .1 & & No & 2011 \\
\hline 4.4 .2 & & No & 2011 \\
\hline 4.5 .1 & & No & 2015 \\
\hline 4.5 .2 & & No & 2015 \\
\hline 4.6 & ID06SS11d, CH16SS11, NERI 06-041 & No & 2009 \\
\hline 4.7 & & No & 2013 \\
\hline 4.8 & & No & 2019 \\
\hline \multicolumn{4}{|c|}{ 5. Safety and Environment } \\
\hline 5.1 .1 & & No & 2011 \\
\hline 5.1 .2 & & No & 2015 \\
\hline 5.2 & ID06SS12c & No & 2007 \\
\hline 5.3 & ID16SS11b & Yes & 2006 \\
\hline 5.4 & INL/EXT-05-00137, ID16SS11a & No & 2009 \\
\hline 5.5 & INL/EXT-05-00453 & No & 2009 \\
\hline
\end{tabular}




\section{ASSESSMENT OF THE MAP}

The materials area is the most populated with projects. Every materials issue listed in the map is receiving at least some attention. No materials technical issue has yet been resolved, and more work will be needed to support the materials down-select decisions that must be made in the near future in regard to heat transfer fluids and candidate materials for pilot-scale heat exchangers and other process units. Overall, the materials work will need to become better prioritized, so that the resources that are available can become more focused on constructing and testing equipment.

Work is progressing in the area of mechanical construction (design), but there are some gaps in the work performed versus what is required. No past or existing project will resolve any of the mechanical construction issues, and more work is needed to generated answers by the required times. So far, no investment has been made in generating concepts for an HTE process heat exchanger. No work has been done in examining options for the alternative processes too, but such design work can wait until there is more resolution concerning which alternative processes might advance to later development stages. No work has been done to define the designs for balance of plant equipment outside of the development of energy and mass balance flow sheets. Work will need to be done in the near term to reconcile the design and materials choices for the heat exchanger and balance of plant components and the materials work, so that the tasks being performed in both areas become more focused on generating workable, dependable, and potentially economic process units.

For the design work that is being performed, some of it is highly idealized and is not immediately useful in regard to constructing actual process units. For example, there is much work underway to model individual flow channels within compact heat exchangers for use with sulfuric acid, but such work doesn't include the effect of having a physical catalyst in the flow channels. Work on analyzing flow channels is important, but so is work that will lead to the design of a whole heat exchanger (including manifolds) or a chemical reactor. At this stage it is more important to show feasibility than to optimize flow channels, and more effort should be placed into generating whole unit designs that may be capable of accomplishing a given task. By examining macroscopic designs, issues related to materials joining, manifolding, catalyst maintenance and replacement, seals, and so forth will be uncovered and can be examined more closely in anticipation of future pilot-scale construction and testing.

In the area of balance of plant and infrastructure requirements, one issue has been resolved - the generation of balance of plant technical requirements for the high temperature electrolysis and sulfur-iodine plants. These requirements may need to be fine-tuned as the flow sheets are updated, but overall, these have largely been defined. Research in this technical area is on schedule and no adjustments are needed in the existing program plans or priorities.

In the area of operation, the higher priority areas are receiving the necessary attention either through national laboratory projects or from university projects funded through the NERI program. This work is progressing on schedule and will not require any significant adjustments to the existing program plans or priorities.

The area of safety and environment, more work is needed to examine the safety and regulatory aspects of co-locating the nuclear plant and the hydrogen plant and on isolation of the 
nuclear island. The work that has been performed so far is a good start, but this work will need to be closely tied in with the latest flow sheets and proposed process unit construction in order to more accurately assess process volumes, pressures, and the specific hazards associated with individual process units. The layout of plants will need to be optimized to maximize process safety while minimizing heat and energy losses, and much work will be needed to integrate all of this information together into workable plant layouts.

Overall, there is an imbalance in how the resources are being spent in regard to materials and mechanical designs. The choice of possible materials is broad, and many parallel avenues are being explored according to the interests of the researchers involved. The research needs to be more results- and application-oriented so that the underlying issues related to construction and operation of whole systems can be recognized and solved in time to support the pilot-scale plants. An assessment of the process requirements, materials candidates, and candidate unit designs must be performed, and this assessment should be the driver for which materials or design concepts will receive the most attention. The research must be convergent on solutions rather than divergent, and refocusing on the needs of the hydrogen production processes is one way to do generate forward momentum towards solutions. 


\section{RESEARCH AND DEVELOPMENT DIRECTIONS FOR FY07}

\subsection{UNLV Reorganization}

In the latter half of 2006, the University of Nevada Las Vegas Research Foundation was dissolved and the High Temperature Heat Exchanger Project was placed under control of the University. Dr. Hechanova retained control of the project. This change provides a greater degree of financial flexibility to the project and will allow the University to be more responsive to changes that occur in the national program.

To take advantage of this change, the breadth of technical leadership at UNLV will be expanded to include the naming of four deputy or associate technical directors. These technical directors will be responsible for specific areas of research that occur at UNLV or are sub-contracted by UNLV, and would report to Dr. Hechanova and the national Technical Director for System Interface and Support Systems. The four technical areas will be materials, heat/mass/momentum transfer, liquid salt systems, and surface characterization and chemistry support. Workscope for these technical areas will be decided in detail once the FY07 budget has passed and the exact amount of money available to UNLV for their work is known.

\subsection{Materials}

A materials and component test plan is being developed that will provide criteria for making choices about materials and material/component combinations. A system of Technical Readiness Levels and a peer-review system will be established to govern the testing and acceptance of individual components, and a database that will hold component case files will be established. Once adopted by the project, the system will be applied at first to components falling under the System Interface and Support Systems category, and then at a larger scale to all technologies under the control of the DOE NHI.

Measurement of material mechanical properties, failure characteristics, and corrosion behaviors will continue in FY07, as needed, to support the development of heat exchangers and other equipment for the S-I and high temperature electrolysis processes.

The NERI projects 05-032 ( $\mathrm{SiC}$ ) and 05-132 (FLiNaK) will continue in FY07, and a new NERI project, 06-024 (Ni-Si materials) commenced in the latter half of FY06. These materials projects will be watched, and information gathered from this work will be incorporated into other System Interface and Support Systems projects as appropriate.

More effort beyond the existing project NERI 05-132 and the safety assessment being provided by ID06SS12c needs to be exerted on studying the feasibility of liquid salts as intermediate heat transfer fluids. The NERI project and the FY06 work package sub-task are examining FLiNaK, but there are other liquid salts which might be used too, such as $\mathrm{NaBF}_{4}-\mathrm{NaF}$ or carbonate-based salts. Experimental work will be commenced on the alternative liquid salt choices in order to document their corrosive effects on high temperature metal alloys, ceramics, 
and insulation materials, understand their handling characteristics, and to develop concepts for how to use such fluids in large-scale heat transfer loops. Assessments of reliability, cost, and safety should be made as well. If this work is not performed, then a down select to a gaseous heat transfer fluid (helium, helium-nitrogen, or carbon dioxide) can be expected in 2009 for the pilotscale equipment.

\subsection{Designs}

Mathematical modeling of the sulfuric acid decomposer must begin to include the physical presence of catalysts in the flow channels, or alternatively, examine combinations of heat transfer sections and adiabatic chemical reaction sections. In one case, the catalyst material is intimately connected to the structural material (ID06SS13) and no changes are needed in the modeling approach. In other cases (ID06SS11c, ID06SS11d, ID06SS15d), where a solidsupported catalyst or catalyst coating might be used within flow channels, the flow and heat transfer conditions may be greatly affected by the presence of catalyst, and models should be adjusted in FY07 to understand this perturbation. Cross-checks between the projected design performance and the physical limitations of available materials will be performed to assess design feasibility and to help define areas of future work.

If possible, modeling work should commence on designing an interface/process heat exchanger for the HTE process. This heat exchanger will likely involve a high-pressure gas on the hot side, and a mixture of steam and hydrogen on the cold side. Liquid salts might be considered as a heat transfer fluid on the hot side, but liquid salts should be given a lower priority until it appears that the use of a liquid salts is feasible for the intermediate heat transfer loop, and such an assessment will not be available at least until FY08 (see Materials above). Since this heat exchanger does not use a catalyst, the existing models for compact heat exchangers might be easily adapted to this new application.

If flow loops are required to answer performance-related questions, concrete efforts will be needed in FY07 to design and construct flow loops that are versatile, safe, and sufficient to meet the needs of the NHI program. Such loops, if needed, would be expected to provide data that cannot be obtained or obtained easily from the integrated lab-scale experiments or by batch tests.

Work should continue to analyze heat exchanger concepts for oxygen cooling and units for high temperature oxygen recovery, as was begun in Work Package ID06SS15. Oxygen recovery is an issue affecting all water-splitting hydrogen production techniques, and this work may be universally applicable to S-I and HTE.

The heat exchanger plate analysis method pioneered in Work Package ID06SS12 or other methods might be used that are faster or require less computing power than regular finite-element analysis methods in order to screen concepts. Creative approaches to performing this screening activity are needed to narrow the field and increase the likelihood of success for designs that will ultimately be constructed and tested in the laboratory. It is recommended that approaches for this type of screening activity be developed in FY07, and, if there is time and funding, that screening work be commenced. 


\subsection{Balance of Plant and Infrastructure}

In FY07, work will continue to analyze the balance-of-plant and infrastructure requirements and needs of the leading hydrogen production processes, and the results will be incorporated into existing and future safety assessments. The materials needs and design concepts for balance-of-plant units will be identified and compared to the list of available materials. If materials or design issues are identified, these issues will be prioritized, and then tackled in priority order as funding and work scope permit.

\subsection{Operations}

Work on developing the steady-state components of the HyPEP model (ID16SS11, CH16SS11) will continue, and work will begin on developing transient process models which may become an additional feature of the HyPEP model or may used as stand-alone software to perform safety analyses and to assist in the development of control strategies. An alpha version of HyPEP will be available from KAERI in October 2006. This alpha version will be internally validated against other models and then modified, as needed, so that a beta version of the model can be made available by the end of FY07.

The HyPEP development work will be supplemented by two NERI projects that began in the latter half of FY06 - NERI 06-041 and NERI 06-060. These projects may provide alternative pathways and methods for performing the transient modeling of the NGNP system and the S-I process in particular. These projects will be watched closely, and collaborations between the HyPEP development team and the NERI teams may be pursued in FY07 if it appears advantageous to do so.

\subsection{Safety and Environment}

In FY07, a more detailed look at the safety aspects of co-locating a hydrogen plant near a nuclear plant will be performed. Specific aspects related to the use and development of high temperature isolation valves, hydrogen plant safety countermeasures to reduce the risk of nuclear plant damage, and improvements to the on-going probabilistic safety assessment work will be pursued. Safety information collected from this work will be communicated as needed to other development teams so that process safety becomes an integral part of the overall development work.

Tritium migration from the nuclear plant to the hydrogen plant has been identified as an item of interest to the project. Currently at the INL, Dr. Hirofumi Ohashi of the Japan Atomic Energy Agency (JAEA) is serving as a visiting engineer and will be on-site at the INL through May 2007. Dr. Ohashi has developed codes for JAEA that can simulate the movement of tritium from their High Temperature Test Reactor (HTTR) to a steam-methane reforming plant. This code may be adapted for use in the NGNP project. There also exists a sizable body of knowledge concerning tritium at the INL connected with the fusion development programs, and this could be potentially tapped to develop tritium migration models for the NGNP as well. Dr. Ohashi will work on adapting his model for use with the VHTR and the lead candidate nuclear hydrogen production processes - the Sulfur-Iodine process and high-temperature electrolysis before he departs in May 2007. 


\section{REFERENCES}

1. S.R. Sherman, M.F. Simpson, D. Ginosar, T. Lillo, P. Peterson, R. Ballinger, A. Roy, A. Hechanova, J.H. Kolts, "Reactor/Process Interface Heat Exchanger and Intermediate Loop Technical Issues", ANL W7500-0002-ES-00, Revision 0, September 2004. 


\section{APPENDIX -- PROJECT DESCRIPTIONS}

\subsection{FY 2002}

NERI 02-160:

M. Gorensek, Savannah River National Laboratory, NERI 02-160, "Centralized Hydrogen Production from Nuclear Power: Infrastructure Analysis and Test-Case Design Study." A conceptual design for a Hybrid Sulfur (HyS) process for the centralized production of hydrogen (H2) using an advanced nuclear reactor heat source has been developed and an economic analysis carried out. The flow sheet was modeled using Aspen Plus, and material and energy balances were prepared from the simulation results. Hydrogen production efficiencies were evaluated and the cost of hydrogen produced was projected for an nth-generation plant. Final report to be issued during FY 2006.

\subsection{FY 2003}

None.

\subsection{FY 2004}

ANL W7500-0001-ES-00:

ANL W7500-0001-ES-00, "Reactor/Process Interface Requirements", Revision 0, July 2004. The document describes a set of high-level functional requirements for the reactor/process interface between the nuclear plant and the hydrogen production plant that are components of the Next Generation Nuclear Plant (NGNP). The intimate linking of a nuclear power plant with a hydrogen production plant through a dedicated interface has never before been accomplished. Without an existing interface to copy, the form of the interface must first be defined by determining what functions the interface is supposed to accomplish, how it must perform, and what is expected of the interface in terms of safety, reliability, and other important aspects. These reactor/process interface requirements will help define the form of the interface so that it can be better understood, and issues related to the achievement of the requirements can be identified and solved.

Reactor/process interface requirements are presented in each of the following areas: operational requirements, sensing and control, physical configuration, physical stability, maintainability, physical protection, environmental 
requirements, and requirements related to the area of regulations, codes and standards. Scientific and engineering issues that may arise when attempting to meet the interface requirements are not discussed.

\section{ANL W7500-0002-ES-00:}

ANL W7500-0002-ES-00, "Reactor/Process Interface Heat Exchanger and Intermediate Loop Technical Issues", Revision 0, September 2004. This document identifies technical issues associated with the heat exchangers and the intermediate loop that form part of the reactor/process interface. While there are other parts of the interface that are important electrical systems, physical protection barriers, etc. - the heat exchangers and intermediate loop form the hear of the reactor/process interface, and so must be well understood before any design work can proceed. Though heat transfer loops of increased complexity can be imagined (two-loop systems, three-loop systems, etc.), the technical issues associated with any loop within these more complex systems are the same as are associated with a single intermediate loop, and so solving the technical issues associated with simple intermediate loop systems will apply generically to all more-complex heat transfer networks, regardless of size. It is intended that this document be used to focus and motivate research in directions and areas that will most benefit the advancement of the art.

The technical issues associated with the intermediate heat exchangers and the intermediate loop are divided into four domains: materials, mechanical construction, system interface operation, and safety. In practice, most technical issues cannot easily be divided into these separate domains and often overlap in multiple areas. Also, technical issues are often interrelated, so that solving a technical issue in one area may create issues in other areas. It is recognized that solving all of the technical issues will be an iterative process, but the issue resolution process must start somewhere, and that process begins with the naming and understanding of all known technical issues.

\section{ANL W7500-0003-ES-00:}

ANL W7500-0003-ES-00, "Balance of Plant Requirements for a Nuclear Hydrogen Pilot Plant", Revision 0, September 2004. This document describes the requirements for components and systems that support the hydrogen production portion of the Next Generation Nuclear Plant (NGNP). These systems, defined as the "balance-of-plant" (BOP), are essential to operate an effective hydrogen production plant. Examples of BOP items are: heat recovery and heat rejection equipment, process material transport systems (pumps, valves, piping, etc.), control systems, safety systems, waste collection and disposal systems, maintenance and repair equipment, heating ventilation, and air conditioning (HVAC), electrical supply and distribution, and others.

The requirements in this document are applicable to the four hydrogen production processes currently under consideration in the DOE Nuclear Hydrogen Initiative. These processes are the sulfur iodine (S-I) process, the hybrid sulfur-iodide electrolytic process (SE), the calcium-bromide process (Ca-Br), and high temperature electrolysis (HTE). While some features of the balance-of-plant requirements are common to all hydrogen production processes, some details will apply to the specific needs of individual processes.

\section{INEEL/EXT-04-01791:}


INEEL/EXT-04-01791, “Infrastructure Requirements for a Nuclear Hydrogen Pilot Plant", Revision 0, March 2004. This report describes a set of high-level requirements (needed capabilities) for the infrastructure required to support the pilot plant scale demonstration of prototype nuclear hydrogen production facilities. The pilot-scale facility would use a non-nuclear heat source.

\subsection{FY 2005}

\section{INL/EXT-05-00137:}

C. Smith, S. Beck, B. Gaylean, INL/EXT-05-00137, “An Engineering Analysis for Separation Requirements of a Hydrogen Production Plant and High-Temperature Nuclear Reactor", Revision 0, March 2005. This report provides the methods, models, and results of an evaluation for location a hydrogen production facility near a nuclear power plant. In order to answer the risk-related questions for this combined nuclear and chemical facility, we utilized standard probabilistic safety assessment methodologies to answer three questions: what can happen, how likely is it, and what are the consequences? As part of answering these questions, we developed a model suitable to determine separation distances for hydrogen process structures and the nuclear plant structures. Our objective of the model-development and analysis is to answer key safety questions related to the placement of one or more hydrogen production plants in the vicinity of a hightemperature nuclear reactor. From a thermal-hydraulic standpoint we would like the two facilities to be quite close. However, safety and regulatory implications force the separation distance to be increased, perhaps substantially. Without answering these safety questions, the likelihood for obtaining a permit to construct and build such a facility in the U.S. would be questionable. The quantitative analysis performed for this report provides us with a scoping mechanisms to determine key parameters related to the development of a nuclear-based hydrogen production facility.

\section{INL/EXT-05-00453:}

C. Davis, C. Oh, R. Barner, S. Sherman, and D. Wilson, INL/EXT-05-00453, “ThermalHydraulic Analyses of Heat Transfer Fluid Requirements and Characteristics for Coupling a Hydrogen Production Plant to a High-Temperature Nuclear Reactor", Revision 0, June 2005. Seven possible configurations for a system that transfers heat between the nuclear reactor and the hydrogen and/or electrical generation plants were identified. These configurations included both direct and indirect cycles for the production of electricity. Both helium and liquid salts were considered as the working fluid in the intermediate heat transfer loop. Methods were developed to perform thermalhydraulic and cycle-efficiency evaluations the sizes of various components in the intermediate heat transport loop for the different configurations. The relative sizes of components provide a relative indication of the capital cost associated with the various configurations. Estimates of the overall cycle efficiency of the various configurations were also determined. The evaluations determined which configurations and coolants are the most promising from thermal-hydraulic and efficiency points of view. These evaluations also determined which configurations and options do not appear to be feasible at the current time. 


\section{INL/EXT-05-00690:}

T. Lillo, R. Williamson, T. Reed, C. Davis, D. Ginosar, INL/EXT-05-00690, "Engineering Analysis of Intermediate Loop and Process Heat Exchanger Requirements to Include Configuration Analysis and Materials Needs", Revision 0, September 2005. This report looks at some of the issues surrounding the main components of an intermediate heat transfer loop (IHTL). Specifically, a stress analysis of a compact heat exchanger design under expected operating conditions is reported. Also the results of a thermal analysis performed on two IHTL pipe configurations for different heat transport fluids are presented. The configurations consist of separate hot supply and cold return legs as well as an annular design in which the hot fluid is carried in an inner pipe and the cold return fluid travels in the opposite direction in the annular space around the hot pipe. The effects of insulation configurations on pipe configuration performance are also reported. Finally, a simple analysis of two different process heat exchanger designs, one a tube in shell type and the other a compact or microchannel reactor are evaluated in light of catalyst requirements.

\section{NERI 05-032 (NHI):}

NERI 05-032, "Silicon Carbide Ceramics for Compact Heat Exchangers." In support of DOE's need for high-temperature, compact heat exchangers for the next generation of nuclear plants, this project will develop revolutionary, cellulose-derived-carbon (CDC), silicon carbide ( $\mathrm{SiC}$ ) materials and structures that are impervious to hot hydrogen gas. $\mathrm{SiC}$ materials offer a 10-fold improvement in thermal conductivity over nickel superalloy, but existing manufacturing technology does not support the production of acceptable quality block materials. The unique CDC-SiC materials and manufacturing approach that will be used in the project will permit the development of net-shaped SiC structures and assemblies suitable for use in compact heat exchanger components.

In addition, this project team will develop glass-sealing technology that is critical to sealing residual porosity in the silicon carbide, in order to make hydrogen-impervious seals. These seals have the potential for sealing between ceramic and metal components. Successful completion of this project will enable the development of a new generation of heat exchangers that are capable of continuous operation at temperatures over $900{ }^{\circ} \mathrm{C}$.

The work is being performed at Johns Hopkins University.

\section{NERI 05-132 (NHI):}

Because the interface between the [nuclear] reactor and the hydrogen production system will likely involve long heat transfer paths at elevated temperatures, a heat transport working fluid that has superior heat transfer characteristics would be required. The heat transport fluid should (1) be chemically compatible with the surrounding structural materials, (2) have superior fluid-mechanical and heat transfer properties, and (3) have acceptable safety characteristics under normal and abnormal conditions. This project investigates the potential of molten salt as a possible transport fluid and also investigates the corrosion resistance of structural materials that would come into contact with the molten salt.

The object of this project is to demonstrate that molten fluoride salt can be successfully implemented in a low-pressure intermediate heat exchange loop. This project will focus 
on researching molten fluoride salts as the process-heat transport medium and the corrosion compatibility of surrounding materials with this medium.

The work is being performed at the University of Wisconsin.

\subsection{FY 2006}

\section{ID06SS11a:}

FY06 Work Package ID06SS11 (WBS 4.1), "UNLVRF High Temperature Heat Exchanger Project". Measure tensile properties of nickel-based Alloy C-22, C-276, Waspaloy, and iron-nickel-molybdenum Alloy $800 \mathrm{H}$ at temperatures ranging from ambient to $1000{ }^{\circ} \mathrm{C}$. Work is taking place at UNLV.

\section{ID06SS11b:}

FY06 Work Package ID06SS11 (WBS 4.1), "UNLVRF High Temperature Heat Exchanger Project". Measure corrosion fracture toughness and crack-growth propagation susceptibility of C-22, C-276, Waspaloy, and $800 \mathrm{H}$ at temperatures up to $450{ }^{\circ} \mathrm{C}$ in aqueous solutions of sulfuric acid and sodium iodide. Work is taking place at UNLV.

\section{ID06SS11c:}

FY06 Work Package ID06SS11 (WBS 4.1), "UNLVRF High Temperature Heat Exchanger Project". Perform mechanical and thermal stress analysis of Ceramatec's ceramic sulfuric acid decomposition heat exchanger design by using finite-element computational modeling tools. Work is taking place at UNLV.

\section{ID06SS11d:}

FY06 Work Package ID06SS11 (WBS 4.1), "UNLVRF High Temperature Heat Exchanger Project". Procurement and construction of high temperature heat exchanger test equipment and performance of equipment validation tests. This equipment uses heated nitrogen or air and silicone oil to simulate the fluid flow conditions of high temperature helium and high temperature molten salt. Plexiglas is used for the fluid flow channels. Work is taking place at UNLV.

\section{ID06SS11e:}

FY06 Work Package ID06SS11 (WBS 4.1), "UNLVRF High Temperature Heat Exchanger Project". Analysis of the structure and composition of corrosion layers on candidate materials for the HIx decomposition process. The test materials (coupons of Ta-2.5W, Nb-10Hf, Nb-1Zr, others) were previously exposed to HIx solutions at General Atomics. Work is taking place at UNLV.

\section{ID06SS12a:}

FY06 Work Package ID06SS12 (WBS 4.1), "Materials Design and Modeling for C/SiC Ceramic Heat Exchangers." Refine the mechanical design(s), thermal-hydraulic 
calculations, and steady and transient thermal stress analysis in high-temperature plate heat exchangers. Work is taking place at UC-Berkeley.

\section{ID06SS12b:}

FY06 Work Package ID06SS12 (WBS 4.1), "Materials Design and Modeling for C/SiC Ceramic Heat Exchangers." Identify and demonstrate optimized ceramic heat exchanger materials and fabrication methods, and scale size and design to demonstrate prototypescale fabrication. Work is taking place at UC-Berkeley.

\section{ID06SS12c:}

FY06 Work Package ID06SS12 (WBS 4.1), "Materials Design and Modeling for C/SiC Ceramic Heat Exchangers." Analyze $\mathrm{C} / \mathrm{SiC}$ composite heat exchanger safety issues related to working with high pressure helium, liquid salts, and tritium. Work is taking place at UC-Berkeley.

\section{ID06SS13a:}

FY06 Work Package ID06SS13 (WBS 4.1), "Pt Added Alloy Catalysts." Determine the catalyst effectiveness of Alloy $617+1-2 \mathrm{wt} \% \mathrm{Pt}$ and Alloy $800+1-2 \mathrm{wt} \% \mathrm{Pt}$ for decomposing sulfur trioxide at $800{ }^{\circ} \mathrm{C}$. Work is taking place at MIT.

\section{ID06SS13b:}

FY06 Work Package ID06SS13 (WBS 4.1), "Pt Added Alloy Catalysts.” Design a test article heat exchanger from the Pt-added material. Heatric will manufacture the test article heat exchangers using a compact heat exchanger design. Work is taking place at MIT.

\section{ID06SS14a:}

FY06 Work Package ID06SS14 (WBS 4.1), "Corrosion and Crack Growth Studies of Materials as Functions of Metallurgical Variables and Thermochemical Treatment of Materials." Install a test system for studying corrosion of samples in HIx extractive distillation environments. In FY06, extractive distillation has been chosen as the reference HIx decomposition process for the S-I process. Work is taking place at General Atomics (GA).

\section{ID06SS14b:}

FY06 Work Package ID06SS14 (WBS 4.1), "Corrosion and Crack Growth Studies of Materials as Functions of Metallurgical Variables and Thermochemical Treatment of Materials." Install a crack growth measurement apparatus for studying crack growth behavior in material samples exposed to HIx chemical environments. Work is taking place at GA.

\section{ID06SS14c:}

FY06 Work Package ID06SS14 (WBS 4.1), "Corrosion and Crack Growth Studies of Materials as Functions of Metallurgical Variables and Thermochemical Treatment of 
Materials." Study corrosion and crack growth behavior of selected material samples (Ta$2.5 \mathrm{~W}$, others) in HIx extractive distillation environments. Work is taking place at GA.

\section{ID06SS15a:}

FY06 Work Package ID06SS15 (WBS 4.1), "Ceramic Heat Exchanger Development for Application to NHI Hydrogen Production Processes." Develop design concepts for an oxygen heat exchanger and high temperature oxygen separator. Work is taking place at Ceramatec, Inc.

\section{ID06SS15b:}

FY06 Work Package ID06SS15 (WBS 4.1), "Ceramic Heat Exchanger Development for Application to NHI Hydrogen Production Processes." Perform corrosion testing of select ceramic materials (e.g., SiC, SiAlON, etc.) for oxygen heat exchange and separation. This sub-task supports ID06SS15a. Work is taking place at Ceramatec.

\section{ID06SS15c:}

FY06 Work Package ID06SS15 (WBS 4.1), "Ceramic Heat Exchanger Development for Application to NHI Hydrogen Production Processes." Perform materials corrosion testing on select ceramic materials for application to sulfuric acid decomposition environments. Work is taking place at Ceramatec.

\section{ID06SS15d:}

FY06 Work Package ID06SS15 (WBS 4.1), "Ceramic Heat Exchanger Development for Application to NHI Hydrogen Production Processes." Perform analyses with UNLV of the thermochemical performance of proposed Ceramatec heat exchanger designs for application to the S-I process. Fabricate prototype components in order to assess performance and validate models. This work is taking place at Ceramatec.

\section{ID16SS11a:}

FY06 Work Package ID16SS11 (WBS 4.1), "NHI System Interface and Support Systems Work at the INL." Revise nuclear plant/hydrogen plant spacing report to adjust for reviewer's comments. This sub-task will produce a revision of the document INL/EXT05-00137 that takes a more detailed look at the S-I plant process units and incorporates real chemical plant accident data into the calculation of failure probabilities. Work is taking place at the INL.

\section{ID16SS11b:}

FY06 Work Package ID16SS11 (WBS 4.1), "NHI System Interface and Support Systems Work at the INL." Provide an assessment of codes and standards applicable to a combined nuclear plant/hydrogen production plant facility. Work is taking place at the INL.

\section{ID16SS11c:}


FY06 Work Package ID16SS11 (WBS 4.1), "NHI System Interface and Support Systems Work at the INL." Revise balance-of-plant requirements to take into account individual requirements of the S-I and HTE hydrogen production plants. This sub-task will result in a revised version of ANL W7500-0003-ES-00. Work is taking place at the INL.

\section{ID16SS11d:}

FY06 Work Package ID16SS11 (WBS 4.1), "NHI System Interface and Support Systems Work at the INL." Initiate work on HyPEP (Hydrogen Plant Efficiency Program), software that will allow for the simulation of the NGNP system interface and related systems for the purposes of calculating energy efficiencies and other system characteristics. Work is taking place at the INL.

\section{NERI 06-024 (NHI):}

The goal of this project is to develop materials suitable for use in the sulfuric acid decomposition loop of the sulfur-iodine thermochemical cycle for nuclear hydrogen production. Materials must possess both acceptable corrosion resistance and sufficient ductility for component fabrication and avoidance of catastrophic failure. Nickel-silicon intermetallics show promise for such critical applications as the sulfuric acid vaporizer, vapor superheater, and the decomposer. Past work indicates that adding minor alloying elements to $\mathrm{Ni}_{3} \mathrm{Si}$ provides significant ductility at room temperature (7-10 percent elongation at failure). This is a unique property for high silicon materials, which are usually brittle. $\mathrm{Ni}_{3} \mathrm{Si}$ can also be easily joined by traditional methods such as welding. In addition, preliminary studies indicate that it has excellent corrosion resistance.

In this work, Ni3Si will undergo further development to maximize ductility and corrosion resistance while reducing cost. The effects of adding elements such as niobium, boron, and iron will be analyzed. Microalloying may also be used to improve resistance to expected corrosive impurities in the sulfuric acid processing stream, such as iodine. Finally, the extent to which iron can be substituted for nickel in $\mathrm{Ni}_{3} \mathrm{Si}$ without adversely affecting ductility or corrosion resistance will be studied.

The mechanical properties of these new materials will be documented over a range of temperatures and strain rates. The results will be used to improve material properties and microstructure. As a final test, corrosion-resistant materials will be subjected to flowing sulfuric acid at temperatures comparable to the actual sulfuric acid processing loop (120$400{ }^{\circ} \mathrm{C}$ at $<10,000 \mathrm{psi}$ ) in order to measure corrosion rates. Various fabrication techniques will also be exercised by forming prototype plates, pipes, and forgings.

This work is being performed at the University of Missouri.

\section{NERI 06-041 (NHI):}

This project will develop a dynamic modeling, simulation, and optimization environment for nuclear hydrogen production systems. A hybrid discrete/continuous model design will capture both the continuous dynamics of the nuclear plant, hydrogen plant, and their interface, along with discrete events of the overall system. This will allow researchers to study plant operations and accident scenarios. Researchers can also use it to conduct parameter estimation studies to identify possible improvements in materials, mechanical 
design, and safety issues. The seamless connection between modeling and simulation can help establish optimal control schemes. These schemes can then be tested in the model.

This work is being performed at MIT.

\section{NERI 06-060 (NHI):}

The main goal of this project is to develop a flowsheet for the closed-loop sulfur iodine (SI) cycle for nuclear hydrogen production. This flowsheet will use current advances in acid decomposition and product gas separation to achieve high thermal efficiency. It will result in the development of transient analysis methods for the SI cycle. Although the closed-loop SI cycle has recently been demonstrated on a bench scale, several challenges remain, such as maintaining stable operation, enhancing efficiency, obtaining thermodynamic data for the reactions, coupling to a high-temperature nuclear reactor, and determining transient behavior of the coupled system. This project will develop models to study transient performance of the closed-loop SI cycle. In addition, this research will explore several alternatives to SI cycles that have been proposed.

A model for the General Atomics (GA) SI cycle flowsheet will be developed using ASPEN PLUS and benchmarked with flowsheet simulation results. Flowsheet modifications will be considered using new membrane techniques for efficient separation of the process gases in the SI cycle. A comparative study of a modified flow sheet with the GA flowsheet will then be performed to identify further technical challenges and research needs. A transient analysis model for the nuclear-hydrogen coupled plant will also be developed for use as a tool to derive process control strategies and logic for coupled plant transient scenarios.

This work is being performed at Purdue University.

\section{AL16TC23:}

FY06 Work Package AL16TC23 (WBS 2.2), "Integrated Lab Scale Experiment Facility Preparation." The Integrated Lab Scale (ILS) experiment for demonstration of the Sulfur-Iodine thermochemical cycle will be conducted at General Atomics starting in FY07. Sandia National Laboratory will serve as the system integrator. This work package covers the preparation of the safety envelope for the host facility to support operation of the lab scale experiment, and overseeing the required facility modifications to meet the lab scale experiment safety and operational requirements. Work is taking place at SNL.

\section{AL16TC25:}

FY06 Work Package AL16TC25 (WBS 2.2), "GA Integrated Lab Scale Experiment Integration Activities." The Integrated Lab Scale (ILS) experiment for demonstration of the Sulfur-Iodine thermochemical cycle will be conducted at General Atomics starting in FY07. The ILS will require coordination of process conditions, interface requirements, control approaches, and supporting systems. The GA integration task will support those integration functions. These tasks will be closely coordinated and will require frequent interaction both formal and informal with SNL and the French CEA. This work is taking place at GA. 


\section{CH16TC31:}

FY06 Work Package CH16TC31 (WBS 2.3), "Calcium Bromine Cycles.” ANL will evaluate the $\mathrm{Ca}-\mathrm{Br}$ cycle for nuclear hydrogen production, focusing on the key technical issues that must be addressed to determine commercial viability. During FY06 a GO/NO-GO decision will be made for the cycle mid-year. Two areas of research will be investigated in FY06: ANL will examine cold plasma and electrolytic methods in combination for the hydrogen generation step for $\mathrm{HBr}$ disassociation to $\mathrm{H}_{2}$ at low temperatures $\left(90^{\circ} \mathrm{C}\right)$. It is anticipated that PEM cells may be more expensive in the nearterm, but developments to reduce costs are coming so rapidly that this approach will need serious consideration within the time-frame for an NHI demonstration. For PEM cell development we plan to work with the University of South Carolina. Experimental effort will also investigate the feasibility of a continuous molten spray reactor approach for the $\mathrm{HBr}$ generation step. This work is taking place at ANL and the University of South Carolina.

\section{ID16EL11:}

FY06 Work Package ID16EL11 (WBS 3.1), "High Temperature Electrolysis System Definition." The major tasks within this work package are to finalize the HTE Integrated Lab Scale experiment performance, space and power requirements; complete a document detailing the HTE Integrated Lab Scale experiment stack specification and mechanical design; and to complete a report detailing how might the HTE technique be used with a CANDU reactor for the purposes of generating hydrogen for use to upgrade Athabasca oilsands. This work is taking place at the INL. 